NBER WORKING PAPER SERIES

FINANCIAL EDUCATION AND CHOICE IN STATE PUBLIC PENSION SYSTEMS

\author{
Julie Agnew \\ Joshua Hurwitz \\ Working Paper 18907 \\ http://www.nber.org/papers/w18907 \\ NATIONAL BUREAU OF ECONOMIC RESEARCH \\ 1050 Massachusetts Avenue \\ Cambridge, MA 02138 \\ March 2013
}

We acknowledge and are grateful for generous financial support from the National Bureau of Economic Research. In addition, we are grateful to several individuals who helped us with our data collection by sharing their connections or offering their insight to us about financial education in retirement plans and the public pension market. They include Alicia Munnell, Robert Clark, Keith Brainard, Deborah Dupont, Gay Lynn Bath, Julia Durand, Alison Salka, Donna Blatecky, Wendy Young Carter, Walter Kelleher, Mark Warshawsky, Michael Jurs and Olivia Mitchell. We are also indebted to the many public plan providers who completed our survey and responded to our follow up questions. We regret that we cannot thank them by name but we want to ensure that we maintain their anonymity. We are very appreciative of their time and their enthusiastic support of this research effort. Some of this research was conducted while Dr. Agnew was a Senior Visiting Fellow in 2012 at the Australian School of Business at the University of New South Wales in Sydney, Australia. The views expressed herein are those of the authors and do not necessarily reflect the views of the National Bureau of Economic Research.

NBER working papers are circulated for discussion and comment purposes. They have not been peerreviewed or been subject to the review by the NBER Board of Directors that accompanies official NBER publications.

(C) 2013 by Julie Agnew and Joshua Hurwitz. All rights reserved. Short sections of text, not to exceed two paragraphs, may be quoted without explicit permission provided that full credit, including $\odot$ notice, is given to the source. 
Financial Education and Choice in State Public Pension Systems

Julie Agnew and Joshua Hurwitz

NBER Working Paper No. 18907

March 2013

JEL No. D14,G11,H75,J26

\begin{abstract}
$\underline{\text { ABSTRACT }}$
As more and more public pension systems are shifting away from a defined benefit only framework, the complexity of the financial decisions facing public employees is increasing. This raises some concerns about the financial literacy of participants and their ability to make informed decisions. While surveys addressing financial education in private plans are available, little is known about what types of education and advice are offered in public plans. This paper fills this gap by presenting new results from the first National Public Pension Plan Financial Education Survey. The paper focuses specifically on primary defined contribution and hybrid plans. The results indicate that some form of education or advice is offered by every surveyed plan and that the sponsoring entity is actively involved in the development of the programs. However, it appears that legal uncertainties related to advice and education may be a problem for a few plans. In addition, more rigorous evaluation methods to test programs are needed. The paper concludes with suggestions for areas of future research.
\end{abstract}

Julie Agnew

Mason School of Business

College of William and Mary

P.O. Box 8795

Williamsburg, VA 23185

julie.agnew@mason.wm.edu

Joshua Hurwitz

Center for Retirement Research

at Boston College

140 Commonwealth Avenue

Chestnut Hill, MA 02467

hurwitzj@bc.edu

An online appendix is available at:

http://www.nber.org/data-appendix/w18907 


\section{Financial Education and Choice in State Public Pension Systems}

\section{Introduction}

Until recently, defined benefit plans in the public sector offered public employees a reliable income in retirement without the responsibility of making important investment choices. This has changed in recent years as a shift away from defined benefit only systems to public systems with defined contribution and hybrid plan options has emerged. New employees in these systems now must make critical financial decisions, such as what type of plan to choose and how to allocate contributions among asset choices. In the long run, these decisions will directly affect the employees' financial well being in retirement. Given the documented low levels of financial literacy in the U.S., it is natural to wonder if public plans are helping prepare members to make financial decisions and, if so, what approaches they are taking. While data to answer these questions exist for the private sector where defined contribution plans prevail, there is little public information available to address these questions in the public sector. To fill this gap, this paper presents new survey evidence from large state primary systems with a specific focus on those that offer plan and investment choice. This survey documents the type of financial education and advice offered to members. In addition, the evidence from plans with choice is contrasted with data collected from state systems offering only a defined benefit option.

This paper is laid out as follows. Section 2 begins by discussing why financial literacy matters. The section documents the lack of financial literacy in the U.S. and how it may affect financial decisions. Section 3 continues with a short overview of the literature related to the effectiveness of financial education and advice associated with retirement plans and describes an important legal distinction between advice and education that plan sponsors must consider. In addition, this section addresses the different legal environments facing public and private plans. Section 4 provides details behind the recent public sector shift away from defined benefit only systems and offers reasons why this new trend has lagged the private sector movement. In addition, this section highlights important differences between public and private sector employees and explains why this matters in the context of financial decisions and literacy. Section 5 presents the new results from the National Public Pension Plan Financial Education Survey and contrasts these findings with evidence from the private sector. The final section provides conclusions and implications.

\section{Financial Literacy: Why Might it Matter?}

Studies consistently find that Americans generally lack an understanding of basic financial concepts. For example, Lusardi and Mitchell (2011a) find in a recent survey of American adults that less than one third (30 percent) of respondents can correctly answer three basic questions related to interest rates, inflation and risk diversification. Their findings are in line with earlier studies (for example, Bernheim 1998; Hilgert et al. 2003). Many studies also find that certain demographic groups score significantly lower than others and these patterns are consistent across many countries (Mitchell and Lusardi 2011b). In most studies, women, individuals with less education and younger people underperform in financial literacy tests. As women and the least educated individuals currently have the highest poverty rates in old age and statistics suggest that younger people are not actively saving, these findings are of particular concern (Munnell 2004; Smeeding et al. 2011). ${ }^{1}$

\footnotetext{
1 Workers under 35 have the lowest participation rate in 401(k) plans of any age group (Vanguard 2011)
} 
Additional research suggests that lack of financial knowledge can influence financial decision-making related to retirement. ${ }^{2}$ For example, Lusardi and Mitchell (2011a) find that individuals who cannot correctly answer their basic financial questions are less likely to be retirement planners. They confirm the causality from financial literacy to retirement planning using an instrumental variable approach. Given that research demonstrates that planners accumulate more retirement wealth than non-planners, it follows that low financial literacy can lead to inadequate savings outcomes (for example, Lusardi and Beeler 2007; Lusardi and Mitchell 2007 a,b, 2011). In addition, Mottola and Utkus (2008) find that less financially sophisticated investors are more likely to hold inappropriately conservative asset allocations in their retirement plans leading to substantial welfare losses. Furthermore, Agnew and Szykman (2005) and Brown, Farrell and Weisbenner (2011) find that individuals with less financial knowledge are significantly more likely to invest in the default option. In these cases, if the defaults are not carefully chosen, suboptimal retirement outcomes may result (Goda and Manchester 2010). Taken together, these studies highlight why basic financial literacy matters.

Beyond basic financial knowledge, many Americans also frequently are unaware of the benefits and features of their own retirement plans and display an inability to correctly answer basic questions about common asset types (Choi et al. 2011, Gustman and Steinmeir 2004, Mitchell 1988). We consider plan knowledge and asset awareness to be important components of financial literacy as it seems unreasonable to expect participants to respond appropriately to plan incentives, such as employer matches, or effectively allocate their portfolios if they are unaware of their plan features and asset choices. Research supports this by providing evidence that lack of plan knowledge relates to poor plan decisions. For example, Agnew et al. (2012) find that individuals are less likely to participate in their 401(k) plan if they are unaware that their company offers a match, regardless of the enrollment arrangement. ${ }^{3}$ Furthermore, Brown et al. (2011) report that individuals with basic and more advanced knowledge of their plan features are more likely to make active decisions and not default. Finally, according to Chan and Stevens (2008), individuals who are knowledgeable about their plan features are more responsive to plan features than those who are less informed, who are more likely react to their own misperceptions of the plan features.

One final consideration is that financial illiteracy may also make it difficult for individuals to process the financial information they are given. If they are overwhelmed by the information, they may resort to relying on simple heuristics to make important decisions or procrastinate. In addition, educational materials and decision aids may not be helpful to them. Research suggests that those with low financial literacy are more prone to feelings of 'information overload.' Recent work also suggests that satisfaction and regret with decisions made can be linked to information issues experienced while making the decision (Agnew and Szykman 2011, Brown et al. 2011). More research is needed to fully understand this relationship but these initial findings suggest that this is another problem possibly rooted in financial illiteracy.

\footnotetext{
${ }^{2}$ While this paper focuses on the relationship between financial literacy and financial decisions related to retirement, Lusardi and Mitchell (2011b) provide a short review of additional literature that links financial literacy with other financial decisions, such as stock market participation, borrowing behavior and mutual fund selection. In addition, Calvet, Campbell and Sodini (2009) use an extensive Swedish dataset to relate a financial sophistication index to three commonly made investment mistakes: underdiversification, inertia in risk taking and the disposition effect in direct stockholdings.

${ }^{3}$ One important caveat to this study is that the assumption that the direction of causality runs from plan knowledge to participation was not tested. Therefore, it is possible that participants acquired plan knowledge through their participation.
} 
In total, the evidence presented here provides a convincing argument that not only basic financial knowledge but plan specific literacy and asset awareness matter. Given the documented widespread financial illiteracy in the U.S., these results present considerable challenges to plan sponsors whose members must often make complex financial decisions that will affect their retirement outcomes.

\section{Financial Education and Advice in Retirement Plans: Regulatory Issues and Effectiveness}

Given the complicated financial decisions individuals face in retirement plans, particularly in defined contribution and hybrid plans, questions naturally arise regarding how and if plan providers address financial literacy issues and whether their efforts are effective. One important factor that directly shapes the availability and format of the education and advice provided is the existing legislation focused on financial education and advice. It is relevant as plans sponsors may harbor concerns about their liability if their financial programs lead an individual to an unsatisfactory outcome. Therefore, this section begins with a discussion of the regulatory environment pertaining to retirement plans and financial programs in both the public and private sector. We also provide descriptions of different types of financial education and advice options as defined by law.

One of the most important pieces of legislation that has significantly affected plan education and advice programs is the Employee Retirement Income Security Act of 1974 (ERISA). Concerns about conflicts of interest by plan fiduciaries providing advice for a fee existed when this legislation was drafted. As a result, the act specifically includes 'prohibited transaction rules' disallowing advisors from providing fiduciary-type investment advice that produces fees or benefits to the advisor or its affiliates. Over the ensuing years, written guidance from the Department of Labor (DOL) and the passage of the Pension Protection Act of 2006 (PPA) have provided private plan sponsors with additional clarification regarding the definition of advice, what constitutes education and what type of advice is exempt from the prohibited transaction rules. ${ }^{4}$ This additional legislation and guidance has allayed many liability concerns that in the past may have deterred private plan sponsors from providing education and advice programs to members. Importantly, this guidance and legislation only covers private plans and does not cover public plans.

Public plans face a much more variable regulatory environment than do private plans. According to an industry legal expert, public plans are subject to common law trust principles within individual jurisdictions. These same principles relate to the ERISA standards. However, states vary regarding whether they codify common law trust concepts in statute or rely on case law interpretation. Thus, public plans do not benefit from one national standardized set of guidance and legislation as private plans do. ERISA case law and DOL guidance often play a role when state and local plan sponsors make decisions and, therefore, in practice public plans often follow these guidelines. However, public plans do not receive any of the legal protections afforded to private plans under these acts. Thus, it is not known whether liability concerns might affect the delivery of financial education and advice in some public plans. Therefore, a separate analysis of the public system is necessary to determine whether the various public plans, do or do not offer the financial education and advice programs available in private plans.

So what legally constitutes financial education and advice? As it stands now, guidance from the DOL states that information about plan features, investment alternatives, investing

\footnotetext{
${ }^{4}$ For more background regarding the PPA and past regulations, please see Tyson and Palumbo (2011).
} 
concepts, and asset allocation portfolios designed for hypothetical individuals are considered to be education rather than advice. In addition, there is a fine line drawn between what is considered guidance and advice under the law. According to ERISA, advice is a recommendation that is immediately actionable. Thus, a recommendation to invest in a specific fund is advice but a nearly identical recommendation to invest in a fund type without mention of a specific fund is considered guidance. This is because the latter recommendation is not immediately actionable. This very subtle distinction is clearly illustrated in Chalmers and Reuter (2012). Finally, according to the PPA, advisors can provide recommendations under the PPA 'prohibited transaction exemption' if they are affiliated with the underlying investments as long as they adhere to very specific conditions. Examples include ensuring that an unbiased computer model that has been certified by an independent third party makes the portfolio recommendations or that advisors receive level compensation. As a result of this guidance and legislation, plans now may provide a broad array of educational offerings and advice services to participants. Whether or not these offerings are effective is a continuing source of active academic research, since the time plans began offering financial education. ${ }^{5}$ While not a comprehensive summary, we will now highlight some of the major findings in this area.

Not surprisingly, the financial education and advice programs addressed in the academic research follow the history of the services and education products popular at the time. Early academic research focuses mainly on traditional educational efforts, including written communications about the company's retirement plans, information about the financial markets and/or financial education seminars. Clark and d`Ambrosio (2003) provide a brief summary of this literature. They conclude that these early studies show a positive impact of financial education on savings behavior. Likewise, Bernheim and Garrett (2003) find using a survey of households that the availability of employer-based financial education relates positively to various measures of asset accumulation. Additionally Bayer, Bernheim and Scholz (2009) using evidence from an annual survey of employers offering voluntary savings programs, find that participation rates and contribution rates are higher for companies that offer frequent seminars and the education effects are greater for non-highly compensated employees. Lusardi (2004) also finds financial education seminars can dramatically increase wealth for families with low education and at the bottom of the wealth distribution.

On the negative side, Choi, Laibson, Madrian and Metrick (2002) and Clark and d'Ambrosio (2003) provide evidence that when the effectiveness of employer education is judged based on subsequent investment behavior and not on intentions following the seminar, the success is more limited. New insight from the growing literature in behavioral finance is providing explanations for why this inaction occurs. Most notably, research suggests that individuals follow the path of least resistance (Choi et al. 2006). Therefore, seemingly simple extra steps, for example requiring employees to fill in a large enrollment form, may prove enough of an obstacle to keep many employees from acting on their intentions. In addition, the behavioral finance literature also provides solutions to help employees overcome the psychological barriers they face. For example, new studies show that simplifying processes can improve behavior in these cases. Beshears et al. (2012) test whether providing employees simple "Quick Enrollment" and "Easy Escalation” cards improves savings behavior in retirement plans. They find significant

\footnotetext{
${ }^{5}$ Hastings, Madrian and Skimmyhorn (2012) provide a thorough overview of literature related to financial literacy, financial education and economic outcomes across multiple contexts. They find little consensus on the efficacy of financial education and, like this paper, recommend more rigorous testing of financial education interventions.
} 
increases in participation and contribution rates. In addition, social marketing approaches are proving successful. Lusardi, Keller and Keller (2008) consider obstacles to savings in their university plan and they develop a planning aid to help at-risk new employees overcome selfcontrol issues which triples participation compared to a control group.

More recent research tests new services available via the internet, employs field study approaches and connects survey evidence to administrative data. Clark et al. (2012) provide a summary of a number of different large-scale projects they are working on that include studies using these new approaches. Their research supports earlier findings suggesting that financial education programs improve behavior. They find seminars increase both financial knowledge and retirement plan knowledge immediately and one year following participation in a seminar. They also document in preliminary work that individual retirement goals, such as the respondent's planned age of retirement, are affected by the new knowledge acquired.

Using a field study, Clark et al. (2012) test the efficacy of informational flyers mailed to non-participants and find that this information can significantly increase plan participation for the youngest workers (aged 18-24) versus the control group. However, they report that a significant difference was not found for older individuals. This suggests that a single educational effort or communication approach may not work for all. Choi et al. (2012) also use a field study to test how e-mail communications can affect behavior. Targeted e-mails are a cost-effective way for plan sponsors to educate and communicate with employees. In their study, the researchers find that very small changes, such as the content of e-mail reminders to employees about contributions, influence savings rates. Both papers demonstrate the value of field-testing educational efforts for effectiveness.

Finally, the guidance from DOL and the passage of the PPA have made advice services more available. These advice services come in many forms, including face-to-face consultations, on-line advice engines and managed account services that allow the participant to hand over the management of their 401(k) portfolio to an outside party. Research into these products suggests that different types of advice appeal to different types of people. For example, several studies find that participants opting to use online advice and managed accounts tend to differ based on demographics (Agnew 2009; Madamba and Utkus 2012; Financial Engines and Hewitt 2010). In terms of brokerage services, Chalmers and Reuter (2012) find that younger, less highly educated and less highly paid employees prefer a plan offering broker services to one without. ${ }^{6}$

As far as effectiveness, the results vary. Ameriks (2001) conducts an analysis of the influence of a software-guided system and finds that the advice sessions have "a significant, positive impact on the likelihood that participants will reallocate assets or begin directing contributions to recommended investment accounts that were not being used prior to the guidance session.” Two newer studies written by financial firms who provide these services suggest that managed accounts lead to better portfolios with less extreme allocations, as well as less assets invested in company stock (Madamba and Utkus 2012; Financial Engines and Hewitt 2010). In addition, Chalmers and Reuter (2012) find marked differences between the broker portfolios and non-broker portfolios in public pension plans, with the former associated with greater risk. Finally, participants may be more responsive to advice if they seek it. In an experiment, Hung and

\footnotetext{
${ }^{6}$ Given that the focus of this paper is on retirement plans, which face strict rules about the type of advice that can be provided, this paper will not summarize the recent literature on financial advisors in the retail market where less restrictions exist. There are a number of recent papers that address this area (for example, Haliassos, Hackethal, Jappelli 2011, Mullainthan, Noeth and Schhoar 2012, Bhattacharya, Hackethal, Kaesler, Loos, Meyer forthcoming).
} 
Yoong (2010) find that defined contribution participants that actively seek advice are more likely to follow the advice versus those who receive unsolicited advice. ${ }^{7}$

As is stands now, the extant research provides evidence that retirement plan financial education appears to work and offers mixed evidence regarding advice. The findings also raise questions and suggest that one-size-fits-all approaches may not work for communicating educational facts or providing services. That said, the promising new trend towards field studies and the large-scale projects underway, as well as the opportunity to incorporate behavioral finance theory into educational methods, suggests that many of these questions will be answered in the future. Importantly, the literature stream will benefit from the more rigorous testing methods afforded by the field study approach which can be used to test new ideas as well as confirm old findings.

\section{The Public Sector versus the Private Sector: Plan Trends and Employee Types}

The recent shift towards defined contribution and hybrid plans in the public sector is well documented (Beshears et al. (2011) and Munnell (forthcoming)). This transition away from defined benefit plans has significantly lagged movement in the private market, where in 2008 approximately 69 percent of private sector workers with pension coverage were covered by only a defined contribution option and not a defined benefit plan. In comparison, 97 percent of covered state and local public workers in 2010 were covered by a DB plan. However, this statistic is changing as now 14 states currently offer a primary defined contribution plan component for some or all of their employees. The recent global financial crisis has accelerated the change as fiscal realities have prompted many more states to review their pension systems.

Munnell (forthcoming) attributes the delay in the public transition to defined contribution plans to several factors including, but not limited to, the public sector's relatively higher unionization, more stable firm structure, and less costly regulatory environment relative to the private sector. She also notes that change in the public sector often requires a lengthy political process, which is an obstacle not faced by private firms. Finally, she highlights the distinct nature of the public sector work force, which differs from the private sector across several dimensions. For example, public workers tend to be older, more educated and have longer job tenures. In addition, using the University of Michigan's 1996 Panel Study of Income Dynamics, Munnell (forthcoming) finds highly risk-averse individuals are also significantly more likely to work in the public sector. ${ }^{8}$ She theorizes that employees who are more risk averse, older and with longer job tenures are more likely to favor a defined benefit system. It follows, she contends, that the public sector may have continued to offer defined benefit plans to attract this type of employee.

Statistics also show that a higher percentage of public employees are women compared to the private sector.

\footnotetext{
${ }^{7}$ This is consistent with findings in the organizational behavior literature. For a comprehensive review, see Bonaccio and Dalal (2006).

${ }^{8}$ Munnell's findings are supported by a 2010 survey conducted by ING of 1,026 public employees (excluding K-12 teachers) (ING 2011). The study finds that only 26 percent of the respondents indicate that they are risktakers. Furthermore, using the Merrill-Reid personality typing system, ING reports that a majority consider themselves good team players that prefer stability to risk. Only 9 percent categorized themselves as a "Director," who among other things, is confident, decisive, determined and a risk-taker. When asked about their retirement investment style, 50 percent considered themselves conservative, meaning they wanted to protect savings and avoid losses. Forty four percent were moderate investors and six percent considered themselves aggressive investors.
} 
Table 1 presents an overview of the different types of primary plans offered in each state. To our knowledge, it is the most comprehensive summary of the major public state plans in the U.S. The information in this table was collected from various plan documents. ${ }^{9}$ In the table, under the column header 'Primary Plan Options,' each plan is sorted into a category based on the plan's type (either DC (defined contribution), DB (defined benefit) or hybrid) and how the plan is selected or not selected by employees (Mandatory or Choice). The 'Mandatory DC' and 'Mandatory Hybrid' categories imply that employees have no choice but to participate in that specific plan. Similarly, a 'DB only' categorization indicates that only a DB option is available to the employees. The categories 'DC choice,' 'DB choice,' and 'Hybrid choice' indicate that the plan is part of a 'choice set' from which employees can select their retirement plan. The choice sets are bolded and the default option is denoted with superscript D. It is possible for a state plan to be mandatory for some employees and part of a choice set for others. In this case, both categories are put in the column and the order reflects how many employees have this option available. The category that describes the situation for most of the plan members is listed first.

This table immediately reveals one of the complications of state retirement systems. In many states, there is not one plan available to all employees but often many different plans offered to workers based on their type of employment. This is one reason that understanding the state public plan system is difficult. In addition, plan eligibility may be based on time of hire. In some cases, new employees may be required to join plans that offer choice, while older employees may be restricted to their original options or given an option to change. ${ }^{10}$ It all depends on the state. To add further complexity, in some states, certain employees may be able to choose their type of plan, while at the same time other employees may be required to participate in a plan chosen by the state. This is the current case in Virginia where a subset of state employees, including higher education workers, political appointees and school superintendents, may choose to join an optional DC plan, the ORP, instead of the DB plan that is mandatory for other state employees. This is evident by looking at the 'Primary Plan Options' column under the Virginia state heading. For Virginia Retirement System (VRS), 'DB only' is the first category that is listed and applies to most employees. 'DB choice' is the second category in bold that only applies to the subset. Employees eligible for the ORP plans that choose not to participate are defaulted into the VRS, as indicated by the superscript D next to 'DB choice.' In 2014, new state and local employees and teachers in the state will be enrolled in a new Virginia hybrid plan, with once again a small subset given the choice between the current ORP and the new hybrid.

With regard to financial education, it can be argued that the recent public plan trend towards more choice increases the need for financial literacy in its membership. While the public workforce tends to be more educated, a characteristic generally associated with greater financial literacy, there are certain public constituencies that may need more assistance than others. For example, several public plans cater to K-12 teachers only. ING present statistics from their K-12 public plans documenting that this group tends to be predominately women. This is a group identified by research as having a higher risk for low financial literacy. In addition, the ING survey finds that a large majority of this group have not developed a plan for retirement (ING 2010). Finally, it is still an outstanding question whether the risk aversion of public workers in general adversely influences their financial choices or not. If as a result they invest in

\footnotetext{
${ }^{9}$ The majority of information in Table 1 was collected from state and plan-level Comprehensive Annual Financial Reports (CAFRs), the Public Plans Database (2010), and pension system websites.

${ }^{10}$ In some cases, participants in a closed primary plan classified as "Mandatory" in Table 1, may have had the option to switch to a newly established plan.
} 
inappropriately conservative portfolios, Mottola and Utkus (2008) calculate very high associated welfare costs with this strategy. Therefore, depending on the findings, financial education may also be helpful in this context.

\section{The National Public Pension Plan Financial Education Survey}

For years, the Plan Sponsor Council of America (PSCA) has conducted annual surveys on education provided in private plans. In their 2010 report, they highlight the most common approaches to education among these plans, provide information regarding the different program goals and offer statistics related to the developers of the programs (PSCA 2010). Unfortunately, this type of information is not readily available for public plans and, as a result, little is known about the educational and advice practices in this sector. Seeking to fill this gap, we fielded over the January to June 2012 time frame the first National Public Pension Plan Financial Education Survey. The survey focuses specifically on DC and hybrid state plans. While decisions associated with defined benefit plans sometimes can be complicated, DC and hybrid plans by design require many more choices influencing retirement outcomes. As a result, it is arguable that education and advice are more necessary in these types of savings vehicles.

Table 2, Panels A and B outline the state primary DC and hybrid plans targeted for the survey. We specifically chose large primary state systems. We exclude plans serving very small constituencies. ${ }^{11}$ However, we do include new primary state plans that at the moment may be small but can be expected to cover a substantial number of employees within the next several years. Table 2, Panel A provides a list of the mandatory primary state plans we study while Table 2 , Panel B provides a list of the targeted plans that are offered as part of a selection of plans available to employees. These tables include the market value of the plans assets.

At first glance, these tables may initially lead to some confusion as one state's name may appear under multiple subcategories. For example, Michigan appears under both 'Mandatory Hybrid' and 'Mandatory DC' subcategories in Table 2, Panel A. A closer look reveals that the official plan names that follow the Michigan name in the tables are different. It is these specific plan names that are the keys to understanding the tables. By referring back to Table 1, readers can learn more about each official plan and the types of employees eligible to participate in them. For example, Table 2 lists Michigan's mandatory DC plan as the State of Michigan Defined Contribution plan. Turning back to Table 1 and moving to the Michigan section, we see that this plan is open to all employees formerly eligible for the SERS, JRS, or LRS DB plans and opened in 1997. Under Table 2's mandatory hybrid plan section, the Michigan MPSERS-PPP plan is listed. Once again, we can learn from Table 1 the eligibility for this plan. We find this plan serves only employees of public schools, district libraries, and certain schools and universities.

In addition to the DC and hybrid plans listed in Table 2 Panel A and B, we did solicit responses from major defined benefit systems and city systems. Our full dataset includes approximately 50 percent of the state defined benefit only systems. While not the focus of our research, we will discuss some of the anecdotal findings from their responses later on. Importantly, before survey respondents took the survey, they were told upfront that their responses would be anonymous and aggregated. This was necessary to ensure a high response rate. To adhere to this condition, we will not present results by plan level nor highlight which plans completed the survey.

\footnotetext{
${ }^{11}$ We also exclude privately managed optional defined contribution plans, such as those commonly available for faculty and staff in higher education.
} 
Table 3 provides the aggregated statistics for our survey respondents and our survey population. For mandatory DC and hybrid plans, we have responses for 80 percent of the plans, representing roughly 54 percent of active participants. For DC and hybrid plans that are part of a choice set offered to members, we collected responses from 87 percent of plans, representing 96 percent of active participants. Combined, this equates to a response rate of 84 percent of the possible 25 plans and 69 percent of active participants. For DB plans that are offered as a choice set, we have data on 89 percent of the active population.

Before moving to the discussion of the financial education programs, Table 4 provides information about important features of the plans surveyed, such as the presence of automatic enrollment and automatic escalation, whether a default investment option is offered and vesting. In addition, it provides details regarding what type of employee (new hires only or most employees) have access to these options. This information is relevant as these features are useful ways to guide behavior in plans, especially if members are not financially literate. Practitioners often debate whether certain features like automatic enrollment and automatic escalation should be used as substitutes or complements to financial education and advice. Not surprisingly, when plans are mandatory, automatic enrollment is always offered, whereas this is not the case when plans are part of a choice set. In the latter case, it is likely that the small percentage of plans that offer automatic enrollment in the choice contexts are the default DC and hybrid plans in the set. Automatic escalation is not a feature in most plans regardless of the type. Data presented in Beshears et al. (2011) provides some insight for this finding. In their study of primary defined contribution plans focused on general employees, they find that plans often have mandatory contribution levels for employees. Thus, the employee does not set the contribution level nor, in some cases, have the ability to increase it. As a result, automatic escalation in these instances is not necessary. Another interesting finding is that default investment options exist in plans offered in a choice set. This is also consistent with Beshears et al. (2011) findings that many opt-in plans also have a default investment option. Some plans do offer matches but they are not offered universally. In addition, most plans come with vesting requirements.

Table 5 combines the choice and mandatory DC and hybrid plans and reports the aggregated responses to questions regarding education and advice programs. Of those surveyed, all of the plans offered some sort of financial education and/or advice with the most popular option being one-on-one telephone consultations. The table sorts the options available by the percentage of actives with access to each option. The table also includes an additional measure, the percentage of plans offering the educational program. This allows comparisons with the PSCA data. Often, but not always, the popularity of the option follows the same ranking for these two metrics. The next most popular options available to over 90 percent of the surveyed respondents include group seminars, periodic newsletters, live webinars, and new hire information packets. Additionally, approximately three-quarters of actives have access to third party online financial advice. One-on-one in person consultations and internet options (financial education web component and online videos) are offered to little more than half of actives. While over half the plans use e-mails, it only equates to 19 percent of the active member population. This could indicate smaller plans are using this option more than larger plans. The least popular approach is social media. PSCA's 2010 results report that for private plans, the most popular education provided includes enrollment kits (70.2 percent of plans), seminars/workshops (63.5 percent), internet/intranet (59.3 percent), e-mail (52.5 percent) and fund performance sheets (44 percent). In addition, PSCA reports that 57.6 percent of plans offer investment advice. ${ }^{12}$ Of those

\footnotetext{
${ }^{12}$ All percentages from the PSCA are as a percent of private profit sharing and 401(k) plans surveyed.
} 
offering investment advice, 58.9 percent offer one-on-one counseling, 62 percent offer advice through the internet, 55.5 percent offer a telephone hotline. Less popular are web conferences offered by 18.2 percent.

In terms of who develops the educational programs, we asked plans whether they created the programs in-house or contracted a third party to develop them. A third party could include the contracted record keeper or a company hired specifically to help with education. Table 6 presents the results. This table is sorted in the same order as Table 5, therefore the most available options to actives are listed first. The percentages are based on the number of plans that offer each option. Therefore, the rows sum to 100 percent. Interestingly, the public plans are very involved in the development of their programs. The majority of the programs are either developed by the plan inhouse or in conjunction with a third party. In most cases, with the understandable exception of third party online advice, less than 35 percent of financial education is completely outsourced to a third party for development. In contrast, the 2010 PSCA report indicates that only 36 percent of retirement planning educational programs are offered by the plan sponsor. In a text response, we asked what third party groups were employed. Interestingly, a few plans had several different providers creating their financial education programs. For example, one firm designed their workshops, another firm handled communications and a third firm provided the advice.

Figure 1 provides more insight into the different topics that are covered. Most types of educational offerings cover both plan specific and general financial knowledge topics. ${ }^{13}$ Table 7 , Panels A and B include more detail regarding the popularity of the topics within each main area (plan specific and general). Table 7, Panel A provides information about plan specific topics. Plans were permitted to choose more than one topic. In most cases, the most popular plan specific topic is a plan overview, with plan investment options and plan distribution options competing for second. Third party online advice is the only educational program that is more likely to cover plan investment options and distribution options than provide a plan overview. Regarding general financial topics (Table 7, Panel B), retirement planning dominates all other topics in all but one case, with diversification, overview of assets and basic investment principles generally ranking second or third. Other topics that are covered by some plans but are not as popular as those listed include debt management, inflation, compound interest, and budgeting.

Finally, the plans list their main goals for financial education as improving overall retirement outcomes (95 percent), highlighting the importance of retirement savings (95 percent) and helping members make better investment decisions (90 percent). The PSCA reports list the most common reasons plans cite for their plan education is to increase participation (79 percent), to increase appreciation for the plan (77 percent) and to increase deferrals (74 percent). Increasing participation and increasing deferrals could both fit under the classification of improving overall retirement outcomes. Thus, the results are fairly consistent. However, increasing the appreciation for the plan was not an option provided as a possible response in the survey so it is not clear whether this is a factor for public plans.

We also asked respondents whether they measured the success of their programs, and their responses are in Table 8 . As the earlier literature review suggests, this is relevant because not all educational methods are effective overall or for specific groups. We find roughly eighty percent of our DC and hybrid plans surveyed measure success. Based on the total surveyed DC and hybrid plans indicating they measure success, about 90 percent use surveys and attendance records to assess performance. These approaches are often useful for capturing participant

\footnotetext{
${ }^{13}$ Some the plans indicate that they do not offer plan specific or general financial education topics. We are following up with these plans to confirm their responses.
} 
satisfaction but, as previously discussed in Section 3, can fall short if participants are not following through with what they have learned. In terms of following actual member decisions made, about 40 percent of plans track default rates and just 35 percent follow actual participant behavior. Only two plans have employed an experimental field study to test for statistically significant changes in behaviors.

With regards to tracking defaults, the Florida Retirement System (FRS) provides a useful case study to illustrate how plans measure success related to defaults. The FRS gave us permission to include and discuss their results. For background, the FRS is the fourth largest public pension plan in the U.S. in size and since 2002 has required new public employees within the first five months of hire to decide whether they want to participate in the DB plan, called the FRS Pension Plan, or the DC option, referred to as the FRS Investment Plan. This is a critical retirement decision for new employees, complicated by the fact that they have limited time to make their choice, while at the same time starting a new job. If no election is made, workers are defaulted into the Pension Plan. These participants are also given one $2^{\text {nd }}$ election opportunity to switch plans during their active career. ${ }^{14}$ The State Board of Administration of Florida (SBA) manages the Investment Plan and has the responsibility to help members choose the appropriate plan through financial education and planning tools. An important goal set by the SBA is to promote active and informed decision-making. As a result, they track the default choices made by new employees and strive to ensure that members defaulting do so actively. ${ }^{15}$ Towards this goal, they hired a third party in 2005 to improve and simplify their plan communications using focus groups to guide the process. They refined the communication and education products over the 2007-2010 time frame. Figure 2 presents a chart that displays how the default rate has declined over time. They estimate that up to 41 percent of those listed as defaulters did so actively. The declining default rate suggests that the communications methods may have worked. However, further econometric analysis is warranted to judge significance. Regardless, Florida provides an excellent example of how one plan is actively following and evaluating decision-making around their education program. They are taking an important step beyond measuring satisfaction with educational materials that others may wish to follow.

Finally, respondents were given the opportunity to provide free text responses to discuss the issues they face offering educational programs and what they would like to know about other public plans. The responses to questions asking respondents what they view as the single largest problem with financial education gives valuable insight into the challenges facing plans. Several plans mentioned that their members' lack of financial literacy/sophistication was an issue, as was helping a diverse membership that includes a broad range of investing expertise and interest level. Several plans mentioned that getting the message to start saving early for retirement was difficult to deliver, as well as encouraging individuals to act on the information they are given. In particular, reaching young people was a common concern. Two plans also mentioned budget constraints.

Interestingly, one plan mentioned concern over crossing the line into financial advice. This comment reveals that the legal issues discussed earlier related to education and advice may affect some public plans. Finally, two plans mentioned the need to better reach out to members at important life milestones. The number of responses to the question asking plans what they would

\footnotetext{
14 After eight years of service in the FRS Pension Plan or FRS Investment Plan (five years for members hired prior to July 1, 2011), members may also choose to participate in the FRS Investment Plan Hybrid Option.

${ }^{15}$ This means their intention is to participate in the Pension Plan and they knowingly allowed themselves to be defaulted into it.
} 
like to know about what other plans are doing demonstrated a general interest in learning more about best practices. Methods for evaluating plan success, encouraging young workers to engage and save, and promoting supplemental savings were topics of interest. One plan wanted to know whether members value in-person education or if they prefer new electronic methods. Additionally, they wondered if life events are targeted.

Overall, the survey results suggest that large state primary public DC and hybrid systems are offering a variety of education programs and that the sponsors play a large role in their development. Plans are interested in measuring success but are more likely to use standard approaches like satisfaction surveys than more rigorous methods like tracking behavior or field studies. Nevertheless, the responses indicate an interest in improving educational approaches and measuring performance.

Finally, we did gather data on 40 primary state defined benefit only plans, representing about 5 million active members and $\$ 1$ trillion in market assets. We close this section by contrasting our previous findings with this sample. To create our target population of defined benefit only plans we used Boston College's Public Plans Database (PPD). This database provides actuarial, financial, and membership data on 107 state plans, representing over 90 percent of total actives and assets covered by state plans. From the database, we identified 92 'DB only' plans. This target sample excludes the plans classified as 'DB Choice' and encompasses about 10 million active members and $\$ 2$ trillion in market assets. ${ }^{16}$ As a result, our DB only sample from the survey represents 43 percent of the PPD sample of DB only plans, and about 50 percent of its active members and market assets. We find that not all of the DB only plans surveyed offer financial education, 80 percent of our surveyed sample does compared to 100 percent of our DC and hybrid sample. Plans not offering education were asked whether they would like to know about what other plans are doing with financial education. Interestingly, two DB plans not offering financial education specifically asked about the legal implications of offering education. Both were interested in learning more about the regulation, which indicates that there is some confusion about what is acceptable. Turning to those DB plans offering education, it is not surprising that the relative importance of some goals are different relative to the DC and hybrid plans. For example, when we look at our sample of 32 defined benefit only plans offering education, the importance of helping people make better investment decisions is only listed by about 40 percent of the plans. That said improving overall retirement outcomes (81 percent) and highlighting the importance of retirement saving (69 percent) are still chosen by a large number of plans and are consistent with the earlier sample. In general, comments from all types of DB plans echoed concerns voiced by earlier plans, such as how to engage the younger population. Finally, one plan expressed interest in how plans successfully locate member e-mails. Anecdotally, the researchers found that some very large plans had similar issues, making use of targeted e-mails and follow ups very difficult.

\section{Conclusions and Implications}

Prior literature suggests that financial literacy is low in the United States. This is a concern as the shift from defined benefit plans to defined contribution and hybrid arrangements continues in both the private and public sector. While the shift is near complete in the private sector, the public sector has lagged behind and only now is experiencing a major transition. Given the complicated decisions employees face in non-DB plans, employers must carefully consider

16 When possible we provided data updates to the database results. 
whether to offer financial education and advice to help their members with important choices. The literature suggests that these efforts can be helpful and new research applying more rigorous testing of effectiveness through field studies promises to provide greater insight into what methodologies will lead to better outcomes.

While surveys addressing financial education in private plans are available, little is known about what is offered in public plans. In addition, given the different characteristics of public sector workers and the variable legal environment facing public plans with respect to education and advice programs, it cannot be assumed that the private plan findings apply directly to public plans. To address this, this paper provides a new analysis of the public market, specifically focusing on large state systems with primary DC and/or hybrid plans. We find that some form of education or advice is offered in every surveyed plan and that the sponsoring entity is very involved in the development of the program. However, it appears that legal uncertainties may be a problem for a few plans.

While many plans attempt to measure success, these plans most frequently use methods such as seminar attendance and surveys to judge performance, which at times can be poor measures of effectiveness. Only 41 percent tracked the default rate on important decisions and 35 percent tracked actual post education behavior. These low percentages leave room in many plans for more rigorous evaluation.

The text responses by survey respondents provide further insight into the challenges facing public plans and indicate that many plans are seeking ways to improve their financial education. In some cases, budget issues can make this a difficult task. In fact, seventy one percent of our sample indicate that with an unlimited budget they would direct more to financial education. Additionally, many plans of different types indicated in the survey that they would be willing to allow further analysis of their approaches to education. In light of this expressed interest, budgetary concerns and desire for improvement, public plans may benefit by forming partnerships with academics interested in testing financial education delivery methods. Such partnerships would allow plans to rigorously test their offerings in a cost effective manner while providing academics an opportunity to further research in their field. Published research would also benefit other plans developing programs.

For academics, studying financial education in public plans provides many interesting research opportunities. Important areas of study that require more in depth analysis include determining what types of members are attracted to various types of educational programs. Is there a bias? Are members that are more inclined to act also more likely to attend events or use resources available? If so, are there effective ways to reach those who do not voluntarily attend or seek assistance? Could mandatory training work? Given the documented risk aversion of public employees, are there more effective ways of reaching this group? What role can e-mail reminders and just-in-time education play in nudging members into action? Can financial education and advice lead to more long-term satisfaction with the decisions that are made? What particular educational methods are most likely to engage and motivate younger employees? These are just a few of the important unanswered questions in this area.

In conclusion, this paper provides a basic review of current educational and advice practices in the public sector and identifies areas in need of improvement. These areas of concern present opportunities for academics and sponsors of public plans to work together to help members achieve better retirement outcomes. Given the new analysis methods being used in the research literature and the advances in the behavioral finance field, the future for better program 
evaluation and the potential for developing new and innovative ways to educate and provide advice looks promising. 


\section{References:}

Agnew, Julie R. 2009. Personalized retirement advice and managed accounts: Who uses them and how does advice affect behavior in 401(k) plans? Working Paper.

Agnew, J.R., Szykman, L.R., 2005. Asset allocation and information overload: The influence of information display, asset choice, and investor experience. Journal of Behavioral Finance 6, 57-70.

Agnew, J.R., Szykman, L. R., 2011. Annuities, financial literacy and information overload, in: Mitchell, O.S., Lusardi, A. (Eds.) Financial Literacy: Implications for Retirement Security and the Financial Marketplace. Oxford University Press, New York, pp. 158-180.

Agnew, J.R., Szykman, L.R., Utkus, Stephen P., Young, Jean A., 2012. Trust, plan knowledge and 401(k) savings behavior. Journal of Pension Economics and Finance 11, 1-20.

Ameriks, J., 2001. The response of TIAA-CREF participants to software driven asset allocation guidance. TIAA-CREF Working Paper 3-080101.

Bayer, P.J., Bernheim, B.D., Scholz, J.K., 2009. The Effects of Financial Education in the Workplace: Evidence from a Survey of Employers. Economic Inquiry 47, 605-624.

Bernheim, B.D., 1998. Financial illiteracy, education and retirement savings, in: Mitchell, O.S., Schieber, S.J. (Eds.), Living with Defined Contribution Pensions. University of Pennsylvania Press, Philadelphia, pp. 38-68.

Beshears, J., Choi, J.J., Laibson, D., Madrian, B.C., 2011. Behavioral economics perspectives on public sector pension plans. Journal of Pension Economics and Finance 10, 315-336.

Beshears, J., Choi, J.J., Laibson, D., Madrian, B.C., 2012. Simplification and Savings. Review of Finance, 1-38.

Bernheim, B.D., Garrett, D.M., 2003. The effects of financial education in the workplace: evidence from a survey of households. Journal of Public Economics 87, 1487-1519.

Bhattacharya, U., Hackethal, A., Kaelser, S., Loos, B., Meyer, S., 2012. Is unbiased financial advice to retail investors sufficient? Answers from a large field study. Review of Financial Studies 25, 975-1032.

Bonaccio, S., Dalal, R.S., 2006. Advice taking and decision-making: An integrative literature review, and implications for the organizational sciences. Organizational Behavior and Human Decision Processes 101, 127-151.

Brown, J.R., Farrell, A.M., Weisbenner, S.J., 2011. The downside of defaults. Working Paper.

Calvet, L.E., Campbell, J.Y., Sodini, P., 2009. Measuring the Financial Sophistication of Households. The American Economic Review 99, 393-398.

Chalmers, J., Reuter, J. 2012. What is the impact of financial advisors on retirement portfolio choices and outcomes? Working Paper.

Chan, S., Stevens A. H., 2008. What you don't know can't help you: Pension knowledge and retirement decision-making. The Review of Economics and Statistics 90, 253-266.

Choi, J.J., Haisley, E., Kurkoski, J., Massey, C., 2012. Small cues change savings choices. Working Paper.

Choi, J.J., Laibson, D., Madrian, B.C., Metrick, A. 2002. Defined contribution pensions: Plan rules, participant decisions and the path of least resistance, in: Poterba, J. (Ed.) Tax Policy and the Economy, Cambridge, MA: MIT Press, pp. 67-113.

Choi, J.J., Laibson, D., Madrian, B.C., Metrick, A. 2006. Saving for retirement on the path of least resistance, in: McCaffrey, E. and Slemrod, J. (Eds.) Behavioral Public Finance: Toward a New Agenda, New York: Russell Sage Foundation, pp. 304-351. 
Choi, J.J., Laibson, D., Madrian, B.C., 2011. \$100 bills on the sidewalk: suboptimal investment in 401(k) plans. The Review of Economics and Statistics 93, 748-763.

Clark, R. L., d'Ambrosio, M.B., 2003. Ignorance is not bliss: The importance of financial education.TIAA-CREF Institute Research Dialogue 78, 1-14.

Clark, R.L., Morrill, M.S., Allen, S.G., 2012. Effectiveness of Employer-Provided Financial Information: Hiring to Retiring. American Economic Review 102, 314-318.

Financial Engines and Hewitt Associates. 2010. Help in defined contribution plans, Industry Report. website: http://corp.financialengines.com/employer/DCHelpReport_Jan2010.pdf

Goda, G.S., Manchester, C.F., 2012. Incorporating employee heterogeneity into default rules for retirement plan selection. NBER Working Paper 16099.

Gustman, A.L., Steinmeier, T.L., 2004. What people don't know about their pensions and Social Security, in: Gale, W.G., Shoven, J.B., Warshawsky, M. (Eds.), Private Pensions and Public Policies. Brookings Institution, Washington, D.C.

Haliassos, M., Hackethal, A., Jappelli, T., 2011. Financial Advisors: A Case of Babysitters?, Working Paper.

Hastings, J.S., Madrian, B.C., Skimmyhorn, W.L., 2012. Financial Literacy, Financial Education and Economic Outcomes. National Bureau of Economic Research Working Paper 18412.

Hilgert, M.A., Hogarth, J.M., Beverly, S.G., 2003. Household financial management: The connection between knowledge and behavior. Federal Reserve Bulletin.

Hung, A. A., Yoong, J.K.,2010. Asking for help: Survey and experimental evidence on financial advice and behavior change. Rand Working Paper WR-714-1.

ING Retirement Research Institute. 2011. Public employees in focus: ING studies the economic outlook of today's government workers. website: https://ing.us/rri/sites/ing.us.rri/files/versioned/Public-Employees-in-Focus-White-Paper.pdf

ING Retirement Research Institute. 2010. The ING Educator's Economic Index: Lessons learned about today's educators. website: http://ing.us/rri/ing-studies/ing-educators-economic-index

Lusardi, A. 2004. Saving and the effectiveness of financial education, in: Mitchell, O.S.,Utkus, S. (Eds.), Pension Design and Structure: New Lessons from Behavioral Finance. Oxford University Press: Oxford, pp. 157-184.

Lusardi, A., Beeler, J., 2007. Redefining retirement: How will boomers fare? in: Madrian, B.C., Mitchell, O.S., Soldo, B. (Eds.), Redefining Retirement: How Will Boomers Fare. Oxford University Press, pp. 271-295.

Lusardi, A, Keller, P. A., Keller, A. M.. 2008. New ways to make people save: A social marketing approach. in: Lusardi, A. (Eds.) Overcoming the saving slump: How to increase the effectiveness of financial education and savings programs, Chicago: University of Chicago Press. 209-36.

Lusardi, A., Mitchell, O.S., 2007a. Financial literacy and retirement preparedness: Evidence and Implications for Financial Education. Business Economics 42, 35-44.

Lusardi, A., Mitchell, O.S., 2007b. Baby Boomer Retirement Security: The Roles of Planning, Financial Literacy, and Housing Wealth. Journal of Monetary Economics 54, 205-224.

Lusardi, A., Mitchell, O.S., 2011a. Financial literacy and retirement planning in the United States. Journal of Pension Economics and Finance 10, 509-525.

Lusardi, A., Mitchell, O.S., 2011b. Financial literacy around the world: an overview. Journal of Pension Economics and Finance 10, 497-508.

Madamba, A., Utkus, S., 2012. Professionally managed allocations: Participant usage and impact. 
Vanguard Center for Retirement Research. website: institutional.vanguard.com

Mitchell, O.S., 1988. Worker Knowledge of Pension Provisions. Journal of Labor Economics 6, 21-39.

Mullainthan, S., Noeth, M., Schoar, A., 2012. The Market For Financial Advice: An Audit Study. NBER Working Paper 17929, 1-34.

Munnell, A.H., 2004. Why are so Many Older Women Poor? Boston College CRR-JTF Working Paper No. 10.

Munnell, A, H. 2012 (forthcoming). State and Local Pensions: What Now? Brookings Institution Press: Washington D.C.

PSCA. 2010. PSCA's 54th Annual Survey of Profit Sharing and 401(k) Plans. website http://www.cvent.com/events/54th-annual-survey/event-summaryb54e57da73624d14a27e681d848eb068.aspx

Public Plans Database. 2000-2010. Center for Retirement Research at Boston College and Center for State and Local Government Excellence. Chestnut Hill, MA, and Washington, D.C.

Smeeding, T., Thompson,J. Levanon,A., Esra Burak, E., 2011. Poverty and Income Inequality in the Early Stages of the Great Recession. in: Grusky, D., Western, B. and Wimer, C. (Eds.) The Great Recession. New York, Russell Sage,pp. 83-126.

Tyson, W.A., Palumbo, M. 2011. DOL issues final participant advice regulations. Vanguard Strategic Retirement Consulting Regulatory Brief.

Mottola, G. R., Utkus, S.P. 2008. Red, Yellow and Green: Measuring the Quality of 401(k) Portfolio Choices, in: Lusardi, A. (Ed.) Overcoming the Saving Slump: How to Increase the Effectiveness of Financial Education and Savings Programs. Chicago: University of Chicago Press, pp. 119-139.

Vanguard Institutional Investor Group, 2011. How America Saves 2010. 


\section{Table 1: Primary State Plans}

This table provides a summary of all the major primary statewide retirement savings plans and also includes many smaller state plans administered only for certain employee groups. In addition, public university plans that are listed in the financial reports of state governments are included. ${ }^{17}$ It is the most comprehensive list of these plans to date but may omit some smaller plans that could not be identified. All discovered plan design changes through June 2012 are reflected in the table, including prospective changes that have been recently legislated. The table includes a list of employee types covered by the plans, the date the plans began and an indicator (*C) for plans that are closed to new members. If the state offers many plans under one large system, the state plan options are indented under the main system heading. The plan options may include closed plans. In addition, the column entitled Primary Plan Options provides details regarding how NEW members in currently active plans choose their plan. For closed plans, it highlights how the plan was chosen by NEW employees when it was open. 'DB only' indicates that a defined benefit plan is the only plan available to employees. 'DC choice', 'DB choice' and 'Hybrid choice' labels indicate defined contribution, defined benefit, and hybrid plans that are part of a choice set. In some cases, a plan can be a 'DB only' option for a majority of the employees but then for a subset of employees exist as a plan offered in a choice set. In this case, the plan categorization that comes first applies to most employees. Plans that are part of a choice set for employees are bolded. The default plan in a choice set is denoted with a D superscript. A * indicates that the information could not be located. This table was carefully constructed after reviewing state and plan-level CAFRs, the Public Plans Database, legal statutes, and other plan documents. On February 13, 2013, the table was sent out for review to representatives from all state pension systems for which we could identify a contact. All changes suggested before February 25 have been incorporated into the table. Extensive table notes are available upon request.

${ }_{17}$ Note a more comprehensive list of public university plans can be found in Brown and Weisbenner (2013, forthcoming). Brown and Weisbenner includes plans that are not reported in state financial reports. The authors' notes on these plans are available on request. 
Table 1 Primary State Plans: Alabama to Arizona

\begin{tabular}{|c|c|c|c|c|}
\hline State & Plan Name & Primary Plan Options & Type of Employees Covered & Eligibility \\
\hline \multicolumn{5}{|l|}{$\mathbf{A} \mathbf{L}^{1}$} \\
\hline \multicolumn{5}{|c|}{ Retirement Systems of Alabama (RSA) } \\
\hline & $\begin{array}{l}\text { Employees’ Retirement System of Alabama } \\
\text { (ERS) }\end{array}$ & DB only & General state employees, state police, and certain local employees & 1945- \\
\hline & Judicial Retirement Fund of Alabama (JRF) & DB only & Judges, justices, and judicial employees & 1973- \\
\hline & Teachers’ Retirement System of Alabama (TRS) & DB only & Teachers and employees of educational institutions & 1939- \\
\hline \multicolumn{5}{|l|}{ AK } \\
\hline & Alaska Judicial Retirement System (JRS) & DB only & Judges and justices & 1963- \\
\hline & $\begin{array}{l}\text { Alaska Elected Public Officers Retirement System } \\
\quad \text { (EPORS) } * \mathrm{C}\end{array}$ & DB only & Governor, Lieutenant Governor, and legislators & $1976-1976$ \\
\hline & $\begin{array}{l}\text { Alaska National Guard and Alaska Naval Militia } \\
\text { Retirement System (NGNMRS) }^{2}\end{array}$ & DB only & Members of the Alaska National Guard and Alaska Naval Militia & 1973- \\
\hline & \multicolumn{4}{|l|}{ Alaska Public Employees’ Retirement System (PERS) } \\
\hline & Defined Benefit Plan (PERS-DB) ${ }^{*} \mathrm{C}$ & DB only & General state and local employees & 1961-2006 \\
\hline & $\begin{array}{l}\text { Defined Contribution Retirement Plan } \\
\text { (PERS-DCR) }\end{array}$ & Mandatory DC & General state and local employees & 2006- \\
\hline & \multicolumn{4}{|l|}{ Alaska Teachers’ Retirement System (TRS) } \\
\hline & Defined Benefit Plan (TRS-DB) $* \mathrm{C}$ & DB only & Mainly teachers & 1955-2006 \\
\hline & Defined Contribution Retirement Plan (TRS-DCR) & Mandatory DC & Mainly teachers & 2006- \\
\hline \multicolumn{5}{|c|}{ - } \\
\hline & \multicolumn{4}{|l|}{$\begin{array}{l}\text { Arizona Public Safety Personnel Retirement System } \\
\text { Trust }^{3}\end{array}$} \\
\hline & $\begin{array}{l}\text { Arizona Corrections Officer Retirement Plan } \\
\text { (CORP) }\end{array}$ & DB only & Local detention officers and certain State corrections officers & 1986- \\
\hline & Arizona Elected Officials’ Retirement Plan (EORP) & DB only & State, county, and elected city officials and judges & 1981- \\
\hline & $\begin{array}{l}\text { Arizona Public Safety Personnel Retirement System } \\
\text { (PSPRS) }\end{array}$ & DB only & Fire fighters and police officers & 1968- \\
\hline & \multicolumn{4}{|l|}{ Arizona State Retirement System (ASRS) ${ }^{4}$} \\
\hline & System Plan *C & Mandatory DC & State, public school, and certain local employees & 1953-1971 \\
\hline & Defined Benefit Plan & DB only, DB choice ${ }^{\mathbf{D}}$ & State, public school, and certain local employees & 1971- \\
\hline & Arizona Universities’ Retirement Plans & DC Choice & $\begin{array}{l}\text { Faculty, academic and service professionals, and administrative } \\
\text { staff of three universities }\end{array}$ & \\
\hline
\end{tabular}


Table 1 Primary State Plans: Arkansas to California

\begin{tabular}{|c|c|c|c|c|}
\hline State & Plan Name & Primary Plan Options & Type of Employees Covered & Eligibility \\
\hline \multicolumn{5}{|c|}{ 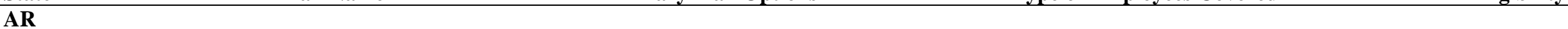 } \\
\hline & Arkansas Judicial Retirement System (AJRS) ${ }^{5}$ & DB only & Judges and justices & 1953- \\
\hline & \multicolumn{4}{|l|}{$\begin{array}{l}\text { Arkansas Public Employee Retirement System } \\
\text { (APERS) }\end{array}$} \\
\hline & $\begin{array}{l}\text { Arkansas Public Employee Retirement System } \\
\text { (APERS) }\end{array}$ & DB only, DB choice & $\begin{array}{l}\text { State and local employees, college and university employees, } \\
\text { certain non-teaching school employees, and judges }\end{array}$ & 1957- \\
\hline & Arkansas State Police Retirement System (ASPRS) ${ }^{6}$ & DB only & Police officers & 1951- \\
\hline & $\begin{array}{l}\text { Arkansas District Judge Retirement System } \\
\quad\left(\text { ADJRS) }{ }^{*} C^{7}\right.\end{array}$ & DB only & District judges & 2005-2007 \\
\hline & $\begin{array}{l}\text { Arkansas State Highway Employees Retirement } \\
\text { System (ASHERS) }\end{array}$ & DB only & Employees of the Arkansas State Highway Department & 1949- \\
\hline & Arkansas Teacher Retirement System (ATRS) & DB only & Teachers, and public school, education, and university employees & 1937- \\
\hline & Arkansas Higher Education Retirement Plans ${ }^{8}$ & DC choice c $^{\mathrm{D}}$ & Higher education employees who work at least 20 hours per week & 1923- \\
\hline \multicolumn{5}{|c|}{ - } \\
\hline & \multicolumn{4}{|l|}{$\begin{array}{l}\text { California Public Employees’ Retirement System } \\
\text { (CalPERS) }\end{array}$} \\
\hline & Public Employees’ Retirement Fund (PERF) & DB only & $\begin{array}{l}\text { General, industrial, and California Highway Patrol employees, } \\
\text { peace officers and fire fighters, and other safety members }\end{array}$ & 1932- \\
\hline & Judges’ Retirement Fund (JRF) ${ }^{*} \mathrm{C}$ & DB only & Judges and justices & 1937-1994 \\
\hline & Judges’ Retirement Fund II (JRF II) & DB only & Judges and justices & 1994- \\
\hline & Legislators’ Retirement Fund (LRF) ${ }^{*} \mathrm{C}$ & DB only & Legislators and constitutional and legislative statutory officers & $1947-1990$ \\
\hline & $\begin{array}{l}\text { California State Teachers’ Retirement System } \\
{\text { (CalSTRS })^{9}}\end{array}$ & DB only & Teachers and other public school employees & 1913- \\
\hline
\end{tabular}


Table 1 Primary State Plans: Colorado to Connecticut

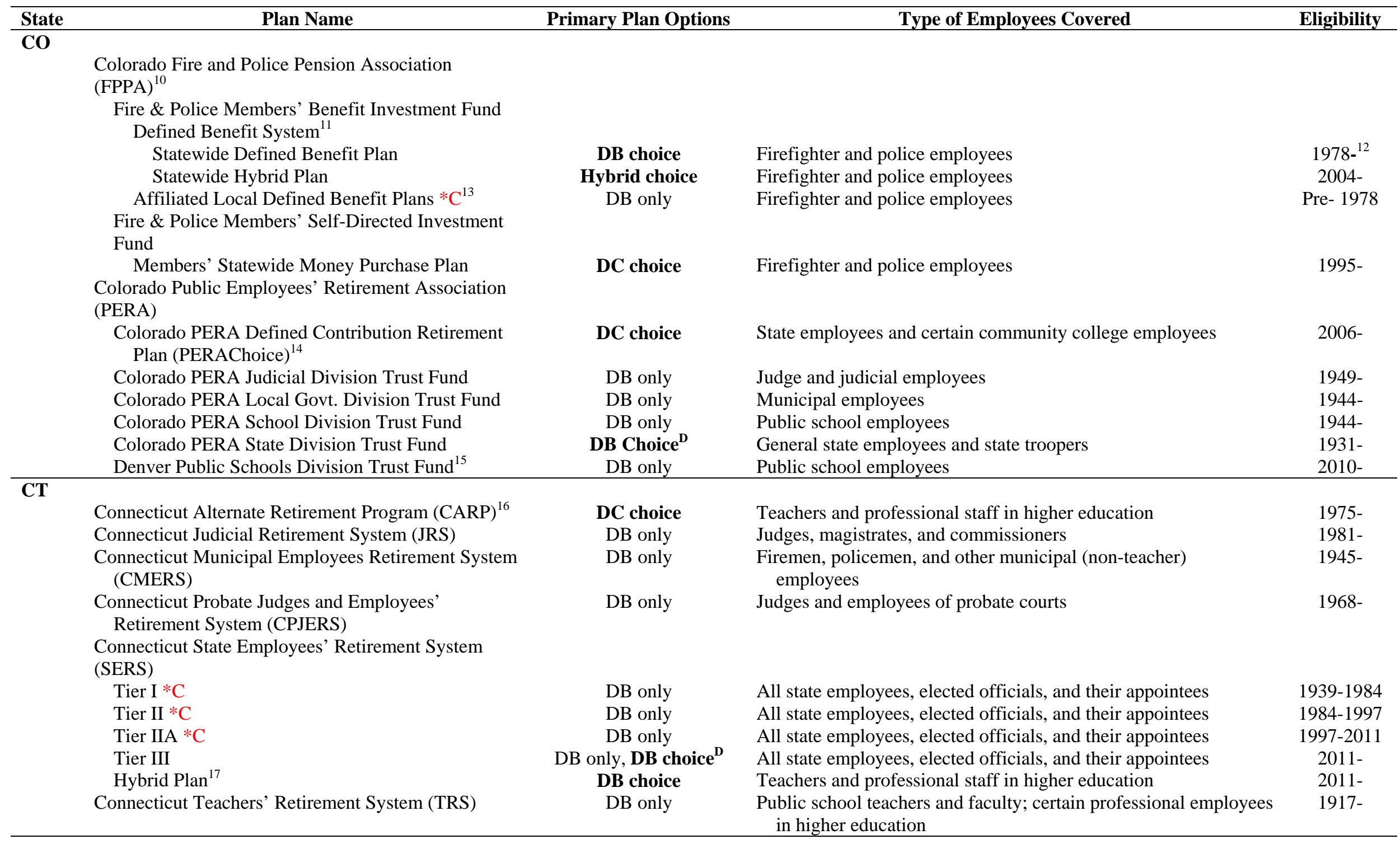


Table 1 Primary State Plans: Delaware to Georgia

\begin{tabular}{|c|c|c|c|c|}
\hline State & Plan Name & Primary Plan Options & Type of Employees Covered & Eligibility \\
\hline \multicolumn{5}{|l|}{ DE } \\
\hline & \multicolumn{4}{|l|}{ 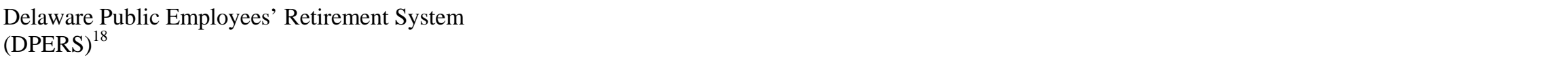 } \\
\hline & $\begin{array}{l}\text { County and Municipal Other Employees’ Pension } \\
\text { Plan }\end{array}$ & DB only & County and municipal employees other than police and firemen & 1987- \\
\hline & $\begin{array}{l}\text { County and Municipal Police and Firefighters’ } \\
\text { Pension Plans }\end{array}$ & DB only & County and municipal police officers and firemen & 1985- \\
\hline & Diamond State Port Corporation Pension Plan & DB only & Employees of the Diamond State Port Corporation & 1996- \\
\hline & Judiciary Pension Plans ${ }^{19}$ & DB only & Members of the Delaware Judiciary & $1970-$ \\
\hline & State Employees’ Pension Plan & DB only & State employees & $1970-$ \\
\hline & State Police Pension Plans ${ }^{20}$ & DB only & State police officers & $1970-$ \\
\hline & Delaware Volunteer Firemen’s Pension Plan & DB only & Fire department, ambulance, and ladies auxiliary volunteers & 1987- \\
\hline \multicolumn{5}{|l|}{ FL } \\
\hline \multicolumn{5}{|c|}{ Florida Retirement System (FRS) ${ }^{21}$} \\
\hline & FRS Pension Plan & DB choice ${ }^{\mathrm{D}}$ & All state employees and participating local employees & $1970-$ \\
\hline & FRS Investment Plan & DC choice & All state employees and participating local employees & 2002- \\
\hline & FRS Investment Plan Hybrid Option & Hybrid choice & All state employees and participating local employees & 2002- \\
\hline & $\begin{array}{l}\text { Senior Management Service Optional Annuity } \\
\text { Program (SMSOAP) }\end{array}$ & DC choice & $\begin{array}{l}\text { Members of the Senior Management Service Class and certain } \\
\text { legislators, managers, and judges }\end{array}$ & 1987- \\
\hline & $\begin{array}{l}\text { State University System Optional Retirement } \\
\text { Program (SUSORP) } \\
\end{array}$ & DC choice & $\begin{array}{l}\text { State university faculty, administrators, and administrative and } \\
\text { professional staff }\end{array}$ & $1984-$ \\
\hline \multicolumn{5}{|c|}{ ( } \\
\hline & \multicolumn{4}{|l|}{$\begin{array}{l}\text { Employees’ Retirement System of Georgia } \\
\text { (ERS System) } \\
\quad \text { Employees’ Retirement System of Georgia (ERS) }\end{array}$} \\
\hline & Old Plan *C & DB only & State employees other than teachers, including police and firemen & 1950-1982 \\
\hline & New Plan *C & DB only & State employees other than teachers, including police and firemen & $1982-2008$ \\
\hline \multicolumn{5}{|c|}{ Plan (GSEPS) } \\
\hline & Pension Plan & Mandatory DB & State employees other than teachers, including police and firemen & 2009- \\
\hline & 401(k) Plan ${ }^{26}$ & Mandatory DC & State employees other than teachers, including police and firemen & 2009- \\
\hline & Georgia Judicial Retirement System (GJRS) & DB only & Judges, attorneys, and legislative counsel & 1998- \\
\hline & Georgia Military Pension Fund (GMPF) & DB only & Georgia National Guard & 2002- \\
\hline & Legislative Retirement System (LRS) & DB only & General Assembly members & 1971- \\
\hline & $\begin{array}{l}\text { Public School Employees Retirement System } \\
\quad(\text { PSERS })^{27}\end{array}$ & DB only & Public school employees not covered by the TRS & $1970-$ \\
\hline & Regents Retirement Plan & DC choice & Eligible university employees choosing not to participate in TRS & 1990- \\
\hline & Teachers Retirement System of Georgia (TRS) & DB only, DB choice ${ }^{\mathbf{D}}$ & Teachers and certain staff of public schools and universities & 1945- \\
\hline
\end{tabular}


Table 1 Primary State Plans: Hawaii to Illinois

\begin{tabular}{|c|c|c|c|c|}
\hline State & Plan Name & Primary Plan Options & Type of Employees Covered & Eligibility \\
\hline \multicolumn{5}{|l|}{ HI } \\
\hline \multicolumn{5}{|c|}{ Hawaii Employees’ Retirement System (ERS) } \\
\hline & Contributory Plan ${ }^{28}$ & DB only & $\begin{array}{l}\text { All state and county employees hired before 6/30/1984; } \\
\text { mandatory occupation groups }\end{array}$ & 1925- \\
\hline & Noncontributory Plan ${ }^{*} \mathrm{C}$ & DB only & $\begin{array}{l}\text { All state and county employees except mandatory Contributory } \\
\text { Plan members }\end{array}$ & 1984-2006 \\
\hline & Hybrid Plan ${ }^{29}$ & DB only & $\begin{array}{l}\text { All state and county employees except mandatory Contributory } \\
\text { Plan members }\end{array}$ & 2006- \\
\hline \multicolumn{5}{|c|}{ ( } \\
\hline & $\begin{array}{l}\text { College and University Optional Retirement Plan } \\
(\text { (ORP) })^{30}\end{array}$ & Mandatory DC & Faculty and staff in higher education & 1990- \\
\hline & Department of Labor Retirement Plan *C & DB only & Idaho Department of Labor employees & Pre- 1980 \\
\hline & Judge’s Retirement Fund (JRF) & DB only & Judges and justices & $*$ \\
\hline & \multicolumn{4}{|l|}{$\begin{array}{l}\text { Public Employee Retirement System of Idaho } \\
\text { (PERSI) }\end{array}$} \\
\hline & $\begin{array}{l}\text { Public Employee Retirement System Base Plan } \\
\text { (PERSI Base Plan) }\end{array}$ & DB only ${ }^{31}$ & $\begin{array}{l}\text { State and school district employees; city, county, and district } \\
\text { employees }\end{array}$ & 1965- \\
\hline & Firemen’s Retirement Fund (FRF) $* \mathrm{C}^{32}$ & DB only & Local firemen & $1940 s-1980$ \\
\hline \multicolumn{5}{|c|}{ 20 } \\
\hline & Illinois General Assembly Retirement System (GARS) & DB only & General Assembly members and certain elected officials & 1947- \\
\hline & Illinois Judges’ Retirement System (JRS) & DB only & Judges and Associate Judges & 1941- \\
\hline & Illinois Municipal Retirement Fund (IMRF) ${ }^{33}$ & DB only & $\begin{array}{l}\text { Local government and non-teaching school district employees, } \\
\text { excluding those in the city of Chicago and Cook County }\end{array}$ & $1941-$ \\
\hline & Illinois State Employees’ Retirement System (SERS) & DB only & Most state employee occupations & 1944- \\
\hline & \multicolumn{4}{|l|}{$\begin{array}{l}\text { Illinois State Universities Retirement System } \\
(\text { SURS) }\end{array}$} \\
\hline & Traditional Plan & DB choice ${ }^{D}$ & $\begin{array}{l}\text { Faculty and staff of state universities, community colleges, and } \\
\text { related agencies }\end{array}$ & $1941-$ \\
\hline & Portable Benefit Option Plan & DB choice & $\begin{array}{l}\text { Faculty and staff of state universities, community colleges, and } \\
\text { related agencies }\end{array}$ & 1998- \\
\hline & Self-Managed Plan & DC choice & $\begin{array}{l}\text { Faculty and staff of state universities, community colleges, and } \\
\text { related agencies }\end{array}$ & 1998- \\
\hline & Illinois Teachers’ Retirement System (TRS) & DB only & Public school teachers & 1939- \\
\hline
\end{tabular}


Table 1 Primary State Plans: Indiana to Iowa

\begin{tabular}{|c|c|c|c|c|}
\hline State & Plan Name & Primary Plan Options & Type of Employees Covered & Eligibility \\
\hline \multirow[t]{18}{*}{ IN } & & & & \\
\hline & Indiana Public Retirement System (INPRS) ${ }^{35}$ & & & \\
\hline & $\begin{array}{l}\text { Indiana Public Employees’ Retirement Fund } \\
\text { (PERF) }\end{array}$ & & & \\
\hline & $\begin{array}{l}1977 \text { Police Officers’ and Firefighters’ Pension } \\
\text { and Disability Fund (PFPF) }\end{array}$ & DB only & Police officers and fire fighters & 1977- \\
\hline & Judges’ Retirement System (JRS) & DB only & Judges and justices & 1977- \\
\hline & Legislators’ Retirement System (LRS) & & & \\
\hline & Legislators’ Defined Benefit Plan *C & DB only & General Assembly members & Pre- 1989 \\
\hline & Legislators’ Defined Contribution Plan & Mandatory DC & General Assembly members & 1989- \\
\hline & Prosecuting Attorneys’ Retirement Fund (PARF) & DB only & Prosecuting attorneys & 1990- \\
\hline & Public Employees’ Retirement Fund (PERF) & Mandatory Hybrid & State and local employees & 1945- \\
\hline & Pension Benefit & Mandatory DB & State and local employees & 1945- \\
\hline & Annuity Savings Account (ASA) ${ }^{36}$ & Mandatory DC & State and local employees & 1955- \\
\hline & State Excise Police, Gaming Agent, Gaming & DB only & Certain employees of the Indiana Department of Natural & 1971- \\
\hline & $\begin{array}{l}\text { Control Officer and Conservation Enforcement } \\
\text { Officers’ Retirement Plan (ECRP) }\end{array}$ & & $\begin{array}{l}\text { Resources, the Indiana Alcohol and Tobacco Commission, and } \\
\text { certain State excise police officers, conservation enforcement } \\
\text { officers, gaming agents, or gaming control officers }\end{array}$ & \\
\hline & State Police Retirement Fund (SPRF) & DB only & State police & 1937- \\
\hline & Indiana Teachers’ Retirement Fund (TRF) & Mandatory Hybrid & Public school teachers and certain employees in higher education & 1921- \\
\hline & Pension Benefit & Mandatory DB & Public school teachers and certain employees in higher education & 1921- \\
\hline & Annuity Savings Account (ASA) ${ }^{36}$ & Mandatory DC & Public school teachers and certain employees in higher education & 1955- \\
\hline \multirow[t]{6}{*}{ IA } & & & & \\
\hline & Iowa Public Employees’ Retirement System (IPERS) & DB only, DB choice ${ }^{\mathrm{D}}$ & $\begin{array}{l}\text { State, county, and local public employees, employees of school } \\
\text { districts, and certain elected officials }\end{array}$ & 1953- \\
\hline & Judicial Retirement System (JRS) & DB only & Judges & * \\
\hline & Municipal Fire \& Police Retirement System of Iowa & DB only & Municipal police officers and fire fighters & 1992- \\
\hline & $\begin{array}{l}\text { Peace Officers’ Retirement, Accident and Disability } \\
\text { System (PORS) }\end{array}$ & DB only & Peace officers & 1949- \\
\hline & $\begin{array}{l}\text { Teachers Insurance and Annuity Association (TIAA) } \\
\text { Retirement Program }\end{array}$ & DC choice & Higher education faculty and staff & $*$ \\
\hline
\end{tabular}


Table 1 Primary State Plans: Kansas to Kentucky

\begin{tabular}{|c|c|c|c|c|}
\hline State & Plan Name & Primary Plan Options & Type of Employees Covered & Eligibility \\
\hline \multicolumn{5}{|c|}{ 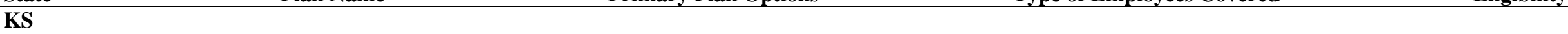 } \\
\hline & Board of Regents' Retirement Plan & Mandatory DC & Employees of state universities and the Board of Regents office & $1962-$ \\
\hline & \multicolumn{4}{|l|}{$\begin{array}{l}\text { Kansas Public Employees Retirement System } \\
\text { (KPERS) }\end{array}$} \\
\hline & $\begin{array}{l}\text { Kansas Police and Firemen’s Retirement System } \\
\text { (KP\&F) }\end{array}$ & DB only & Police officers and firefighters & 1966- \\
\hline & $\begin{array}{l}\text { Kansas Public Employees Retirement System } \\
\text { (KPERS) }\end{array}$ & DB only & $\begin{array}{l}\text { State and public school employees, and employees of counties, } \\
\text { municipalities, and certain other political subdivisions }\end{array}$ & $1962-$ \\
\hline & Kansas Retirement System for Judges & DB only & Judges and justices & 1975- \\
\hline \multicolumn{5}{|c|}{$e^{2}$} \\
\hline \multicolumn{5}{|c|}{ Judicial Form Retirement System } \\
\hline & Judicial Retirement Plan & DB only & Judges and justices & $1960-$ \\
\hline & Legislators’ Retirement Plan & DB only & General Assembly members & 1980- \\
\hline & \multicolumn{4}{|l|}{ Kentucky Retirement Systems (KRS) } \\
\hline & County Employees Retirement System (CERS) & DB only & $\begin{array}{l}\text { Full-time employees of participating counties, cities, school } \\
\text { boards, and any additional local agencies }\end{array}$ & 1958- \\
\hline & Kentucky Employees Retirement System (KERS) & DB only & Full-time employees of any state department, board, or agency & 1956- \\
\hline & State Police Retirement System (SPRS) & DB only & Full-time state troopers & $1960-$ \\
\hline & Kentucky Teachers’ Retirement System (KTRS) & DB only & Employees of local school districts and other educational agencies & 1938- \\
\hline
\end{tabular}


Table 1 Primary State Plans: Louisiana

\begin{tabular}{|c|c|c|c|c|}
\hline State & Plan Name & Primary Plan Options & Type of Employees Covered & Eligibility \\
\hline \multicolumn{5}{|c|}{ 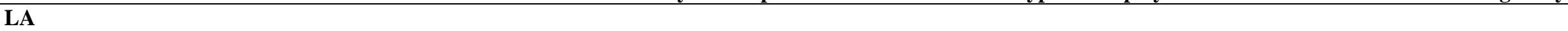 } \\
\hline \multicolumn{5}{|c|}{$\begin{array}{l}\text { Louisiana State Employees’ Retirement System } \\
\text { (LASERS) }\end{array}$} \\
\hline & Regular Employees Plan & DB only & $\begin{array}{l}\text { Regular state employees and specialty positions not covered by } \\
\text { the Hazardous Duty or Judicial Plan }\end{array}$ & 2011- \\
\hline & Regular Employees Plan ${ }^{*} \mathrm{C}$ & DB only & Regular state employees & $1947-2010$ \\
\hline & Hazardous Duty Employees Plan & DB only & Employees in hazardous duty positions & 2011- \\
\hline & Alcohol \& Tobacco Control Agents Plan ${ }^{*} \mathrm{C}$ & DB only & Alcohol and tobacco control officers & $2007-2010$ \\
\hline & Appellate Law Clerks Plan *C & DB only & Appellate law clerks & Pre- 2010 \\
\hline & Bridge Police Plan $* \mathrm{C}$ & DB only & Bridge police for Crescent City Connection & $1997-2010$ \\
\hline & Corrections Primary Plan ${ }^{*} \mathrm{C}$ & DB only & $\begin{array}{l}\text { Correctional officers in Department of Public Safety and } \\
\text { Corrections }\end{array}$ & $1975-2001$ \\
\hline & Corrections Secondary Plan ${ }^{*} \mathrm{C}$ & DB only & $\begin{array}{l}\text { Correctional officers in Department of Public Safety and } \\
\text { Corrections }\end{array}$ & $2002-2010$ \\
\hline & Legislative Plan ${ }^{*} \mathrm{C}$ & DB only & State legislative officers and elected officials & $1959-2010$ \\
\hline & Peace Officers Plan ${ }^{*} \mathrm{C}$ & DB only & Peace officers & 2006-2010 \\
\hline & Wildlife \& Fisheries Plan *C & DB only & Department of Wildlife and Fisheries agents & $1972-2010$ \\
\hline & Judicial Plan & DB only & Elected judges & 1976- \\
\hline & Optional Retirement Plan (ORP) $* \mathrm{C}$ & DC choice & Certain unclassified employees & $1999-2007$ \\
\hline & Louisiana Lottery Corporation Basic Retirement Plan & Mandatory DC & Employees of the Louisiana Lottery Corporation & 1993- \\
\hline & $\begin{array}{l}\text { Louisiana School Employees’ Retirement System } \\
\text { (LSERS) }\end{array}$ & DB only & $\begin{array}{l}\text { School bus drivers, school janitors, school custodians, and school } \\
\text { maintenance employees }\end{array}$ & 1947- \\
\hline & Louisiana State Police Retirement System (LSPRS) & DB only & $\begin{array}{l}\text { Law enforcement officers and the Superintendent of the Office of } \\
\text { State Police }\end{array}$ & 1938- \\
\hline & $\begin{array}{l}\text { Municipal Employees’ Retirement System of } \\
\text { Louisiana }\end{array}$ & DB only & Public employees of incorporated villages, towns, and cities & 1955- \\
\hline \multicolumn{5}{|c|}{ Teachers' Retirement System of Louisiana (TRSL) } \\
\hline & TRSL Regular Plan & DB only, DB choice ${ }^{\mathbf{D}}$ & $\begin{array}{l}\text { Public school teachers, academic employees in higher education, } \\
\text { and certain board members }\end{array}$ & 1936- \\
\hline & TRSL Plan A *C & DB only & School lunch employees without Social Security coverage & $1983-2010$ \\
\hline & TRSL Plan B & DB only & School lunch employees with Social Security coverage & 1983- \\
\hline & Optional Retirement Plan (ORP) & DC choice & $\begin{array}{l}\text { Academic employees in higher education and certain board } \\
\text { Members }\end{array}$ & $1990-$ \\
\hline
\end{tabular}


Table 1 Primary State Plans: Maine to Massachusetts

\begin{tabular}{|c|c|c|c|c|}
\hline State & Plan Name & Primary Plan Options & Type of Employees Covered & Eligibility \\
\hline \multicolumn{5}{|l|}{ ME } \\
\hline & \multicolumn{4}{|l|}{$\begin{array}{l}\text { Maine Public Employees Retirement System } \\
\text { (MainePERS) }\end{array}$} \\
\hline & $\begin{array}{l}\text { Consolidated Plan for Participating Local Districts } \\
\text { (PLDs) }\end{array}$ & DB only & Municipal and other local employees & $*$ \\
\hline & Judicial Retirement System & DB only & Judges & 1984- \\
\hline & Legislative Retirement Program & DB only & Legislators & 1986- \\
\hline & State Employee and Teacher Program (SETP) ${ }^{40}$ & DB only & State employees, public school teachers, and administrators & 1947- \\
\hline \multicolumn{5}{|c|}{ 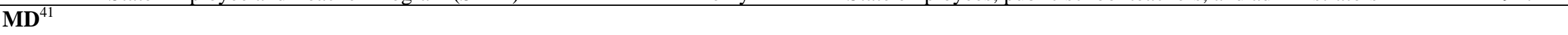 } \\
\hline & \multicolumn{4}{|l|}{$\begin{array}{l}\text { Maryland State Retirement System and Pension } \\
\text { System (SRPS) }\end{array}$} \\
\hline & Correctional Officers’ Retirement System (CORS) & DB only & Municipal correctional officers & $*$ \\
\hline & \multicolumn{4}{|l|}{ Employees’ Combined System (ECS) } \\
\hline & Employees’ Retirement System *C & DB only & State and municipal employees & 1941-1979 \\
\hline & Employees’ Pension System & DB only, DB choice ${ }^{\mathbf{D}}$ & State and municipal employees & 1980- \\
\hline & Judges’ Retirement System & DB only & Judges and members of the State Workers' Compensation Comm. & 1969- \\
\hline & $\begin{array}{l}\text { Law Enforcement Officers’ Pension System } \\
\text { (LEOPS) }\end{array}$ & DB only & Law enforcement officers & 1990- \\
\hline & Optional Retirement Program (ORP) $)^{42}$ & DC choice & Professional employees of public higher education institutions & 1975- \\
\hline & State Police Retirement System & DB only & State police officers & 1949- \\
\hline \multicolumn{5}{|c|}{ Teachers' Combined System (TCS) } \\
\hline & Teachers’ Retirement System *C & DB only & $\begin{array}{l}\text { Personnel of Maryland public schools, public libraries, and } \\
\text { certain colleges }\end{array}$ & 1927-1979 \\
\hline & Teachers’ Pension System & DB only, DB choice ${ }^{\mathbf{D}}$ & $\begin{array}{l}\text { Personnel of Maryland public schools, public libraries, and } \\
\text { certain colleges }\end{array}$ & 1980- \\
\hline \multicolumn{5}{|l|}{ MA } \\
\hline & Optional Retirement Plan (ORP) & DC choice & Public higher education employees & 1995- \\
\hline & State Employees’ Retirement System (SERS) & DB only, DB choice ${ }^{\mathbf{D}}$ & Employees of the Commonwealth & 1911- \\
\hline & Teachers’ Retirement System (MTRS) & DB only & Municipal teachers & 1914- \\
\hline
\end{tabular}


Table 1 Primary State Plans: Michigan

\begin{tabular}{|c|c|c|c|c|}
\hline State & Plan Name & Primary Plan Options & Type of Employees Covered & Eligibility \\
\hline \multicolumn{5}{|l|}{$\mathbf{M I}^{43}$} \\
\hline \multirow{2}{*}{\multicolumn{5}{|c|}{$\begin{array}{l}\text { Municipal Employees’ Retirement System of } \\
\text { Michigan (MERS) }\end{array}$}} \\
\hline & & & & \\
\hline & MERS Defined Benefit Plan & DB choice & Employees of cities, counties, hospitals, and other local gov. units & 1945- \\
\hline & MERS Defined Contribution Plan & DC choice & Employees of cities, counties, hospitals, and other local gov. units & 1996- \\
\hline & MERS Hybrid Plan & Hybrid choice & Employees of cities, counties, hospitals, and other local gov. units & 2006- \\
\hline & \multicolumn{4}{|l|}{$\begin{array}{l}\text { Public School Employees’ Retirement System } \\
\text { (MPSERS) }\end{array}$} \\
\hline & Contributory Plan *C & DB only & Employees of public schools, libraries, and certain colleges & 1945-1977 \\
\hline & Basic Plan *C & DB only & Employees of public schools, libraries, and certain colleges & 1977-1986 \\
\hline & Member Investment Plan (MIP) *C & DB only & Employees of public schools, libraries, and certain colleges & $1987-2010$ \\
\hline & Pension Plus Plan (PPP) & Mandatory Hybrid & Employees of public schools, libraries, and certain colleges & 2010- \\
\hline & $\begin{array}{l}\text { State of Michigan Defined Contribution Retirement } \\
\text { Plan }\end{array}$ & Mandatory DC & $\begin{array}{l}\text { All employees formerly eligible for the SERS, JRS, or LRS } \\
\text { DB plans }\end{array}$ & 1997- \\
\hline & Judges’ Retirement System (JRS) *C & DB only & Judges and elected State officials ${ }^{45}$ & 1992-1997 \\
\hline & Legislative Retirement System (LRS) ${ }^{*} \mathrm{C}$ & DB only & Legislators & 1957-1997 \\
\hline & State Employees’ Retirement System (SERS) ${ }^{*} \mathrm{C}$ & DB only & $\begin{array}{l}\text { Civil service employees, appointed officials in the Executive } \\
\text { branch, employees of the Legislature and Judiciary }\end{array}$ & 1943-1997 \\
\hline & State Police Retirement System (SPRS) & DB only & Sworn State Police officers & 1987- \\
\hline
\end{tabular}


Table 1 Primary State Plans: Minnesota

\begin{tabular}{|c|c|c|c|c|}
\hline State & Plan Name & Primary Plan Options & Type of Employees Covered & Eligibility \\
\hline \multicolumn{5}{|c|}{ 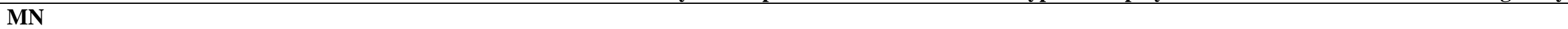 } \\
\hline & Minnesota State Colleges and Universities (MnSCU) & & & \\
\hline & $\begin{array}{l}\text { State Colleges and Universities Retirement Fund } \\
\text { (CURF) }\end{array}$ & DC choice $^{\mathrm{D}}$ & $\begin{array}{l}\text { Unclassified teachers and certain other full-time staff } \\
\text { members in higher education }\end{array}$ & $*$ \\
\hline & Minnesota State Retirement System (MSRS) ${ }^{46}$ & & & \\
\hline & Correctional Employees Retirement Plan & DB only & $\begin{array}{l}\text { Correctional officers and certain employees in the Departments of } \\
\text { Corrections and Human Services }\end{array}$ & 1973- \\
\hline & Elective State Officers Retirement Plan ${ }^{*} \mathrm{C}$ & DB only & State constitutional officers & 1967-1997 \\
\hline & General Employees Retirement Plan & DB only, DB choice & $\begin{array}{l}\text { Most state employees, University of Minnesota non-faculty } \\
\text { employees, and selected metropolitan agency employees }\end{array}$ & 1929- \\
\hline & Judges Retirement Plan & DB only & Supreme Court, Court of Appeals, and district court judges & $1931-$ \\
\hline & Legislators Retirement Plan ${ }^{*} \mathrm{C}$ & DB only & Certain members of the House of Representatives and Senate & $1965-1997$ \\
\hline & State Patrol Retirement Plan & DB only & $\begin{array}{l}\text { State troopers, conservation officers, and certain crime bureau and } \\
\text { gambling enforcement agents }\end{array}$ & 1943- \\
\hline & Unclassified Retirement Plan ${ }^{47}$ & $\begin{array}{l}\text { Mandatory DC, } \\
\text { DC choice }\end{array}$ & $\begin{array}{l}\text { Employees in "unclassified service” of the state, various } \\
\text { statutorily designated employees, legislators, and certain judges }\end{array}$ & $1971-$ \\
\hline \multicolumn{5}{|c|}{$\begin{array}{l}\text { Public Employees Retirement Association of } \\
\text { Minnesota (PERA) }\end{array}$} \\
\hline & General Employees Retirement Fund (GERF) & DB only, DB choice ${ }^{\mathbf{D}}$ & Employees of counties, cities, school districts, and related units & 1931- \\
\hline & $\begin{array}{l}\text { Minneapolis Employees Retirement Fund } \\
\quad(\mathrm{MERF}) * \mathrm{C}^{48}\end{array}$ & DB only & $\begin{array}{l}\text { Regular employees of Minneapolis, certain personnel at } \\
\text { Minneapolis schools, some employees of the MnSCU and the } \\
\text { Metropolitan Airports Commission }\end{array}$ & 1919-1978 \\
\hline & Public Employees Police and Fire Fund (PEPFF) & DB only & $\begin{array}{l}\text { Police officers and firefighters of local government units and } \\
\text { subdivisions of the state }\end{array}$ & 1959- \\
\hline & Public Employees Correctional Fund (PECF) & DB only & Certain employees of county correctional facilities & 1999- \\
\hline & $\begin{array}{l}\text { Public Employees Defined Contribution Plan } \\
(\text { (PEDCP })^{49}\end{array}$ & DC only, DC choice & $\begin{array}{l}\text { Physicians, elected local government officials, city managers, and } \\
\text { governmental ambulance service personnel }\end{array}$ & 1987- \\
\hline & $\begin{array}{l}\text { Statewide Volunteer Firefighter Retirement } \\
\text { Plan (SVF) }\end{array}$ & DB only & Employees of municipal volunteer fire departments & 2010- \\
\hline & Teachers Retirement Association of Minnesota (TRA) & & & \\
\hline & Teachers Retirement Fund (TRF) & DB only, DB choice & Teachers and related professionals & 1931- \\
\hline
\end{tabular}


Table 1 Primary State Plans: Mississippi to Missouri

\begin{tabular}{|c|c|c|c|c|}
\hline State & Plan Name & Primary Plan Options & Type of Employees Covered & Eligibility \\
\hline \multicolumn{5}{|c|}{ 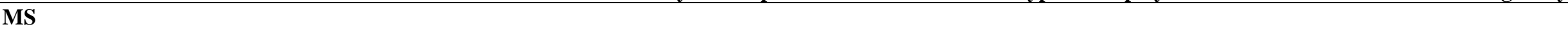 } \\
\hline & \multicolumn{4}{|l|}{$\begin{array}{l}\text { Public Employees’ Retirement System of Mississippi } \\
\text { (the System) }\end{array}$} \\
\hline & $\begin{array}{l}\text { Mississippi Highway Safety Patrol Retirement } \\
\text { System (MHSPRS) }\end{array}$ & DB only & Sworn Officers of the Mississippi Highway Safety Patrol & 1958- \\
\hline & $\begin{array}{l}\text { Mississippi Public Employees’ Retirement System } \\
\text { (PERS) }\end{array}$ & DB only & $\begin{array}{l}\text { Employees of the state, state universities, community and junior } \\
\text { colleges, and public school teachers and employees }\end{array}$ & $1952-$ \\
\hline & Municipal Retirement Systems (MRS) *C & DB only & $\begin{array}{l}\text { Municipal employees, fire fighters, and police officers who were } \\
\text { not already members of PERS }\end{array}$ & Pre- 1987 \\
\hline \multicolumn{5}{|c|}{ (2) } \\
\hline & $\begin{array}{l}\text { Missouri County Employees’ Retirement Fund } \\
(\text { CERF })^{53}\end{array}$ & DB only & Elective or appointee officers and other county employees & 1994- \\
\hline & $\begin{array}{l}\text { Missouri Department of Transportation and Highway } \\
\text { Patrol Employees’ Retirement System (MPERS) }\end{array}$ & DB only & $\begin{array}{l}\text { Qualified employees of the Missouri Department of } \\
\text { Transportation, members of the Missouri State Highway Patrol, } \\
\text { and MPERS staff }\end{array}$ & 1955- \\
\hline & $\begin{array}{l}\text { Missouri Local Government Employees’ Retirement } \\
\text { System (LAGERS) }\end{array}$ & DB only & $\begin{array}{l}\text { General employees and police and fire employees of political } \\
\text { Subdivisions }\end{array}$ & 1967- \\
\hline & \multicolumn{4}{|l|}{$\begin{array}{l}\text { Missouri State Employees’ Retirement System } \\
\text { (MOSERS) }\end{array}$} \\
\hline & Judicial Plan & DB only & Certain judges, justices, and court commissioners & 1976- \\
\hline & Missouri State Employees Plan’ (MSEP) & DB only & Full-time state employees & 1957- \\
\hline & \multirow{2}{*}{\multicolumn{4}{|c|}{$\begin{array}{l}\text { Public School and Education Employee Retirement } \\
\text { Systems of Missouri (PSRS/PEERS) }\end{array}$}} \\
\hline & & & & \\
\hline & $\begin{array}{l}\text { Public School Retirement System of Missouri } \\
\text { (PSRS) }\end{array}$ & DB only & $\begin{array}{l}\text { Certified, full-time employees of public schools, public two-year } \\
\text { colleges, PSRS, and certain non-profit associations }\end{array}$ & 1946- \\
\hline & $\begin{array}{l}\text { Public Education Employee Retirement System of } \\
\text { Missouri (PEERS) }\end{array}$ & DB only & $\begin{array}{l}\text { Certain employees of public schools, public two-year colleges, } \\
\text { and PEERS not covered by PSRS }\end{array}$ & $1965-{ }^{54}$ \\
\hline
\end{tabular}


Table 1 Primary State Plans: Montana to Nebraska

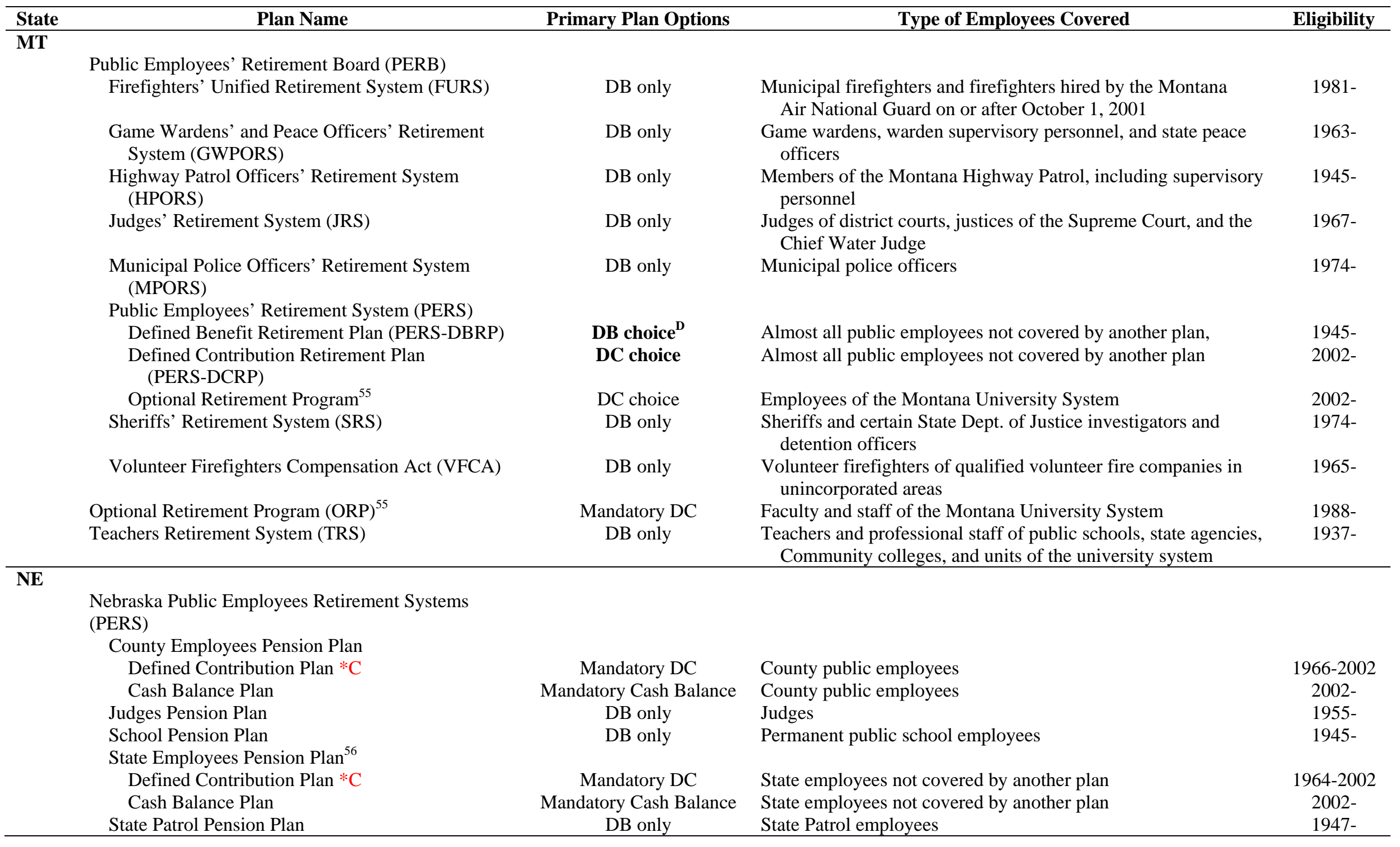


Table 1 Primary State Plans: Nevada to New Jersey

\begin{tabular}{|c|c|c|c|c|}
\hline State & Plan Name & Primary Plan Options & Type of Employees Covered & Eligibility \\
\hline \multicolumn{5}{|c|}{ 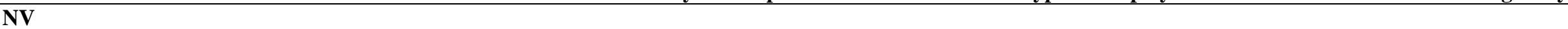 } \\
\hline \multicolumn{5}{|c|}{ Public Employees Retirement Board } \\
\hline & Judicial Retirement System of Nevada (JRS) & DB only & $\begin{array}{l}\text { Justices of the Supreme Court, district judges, municipal } \\
\text { court judges, and justices of the peace }\end{array}$ & 2001- \\
\hline & Legislators’ Retirement System of Nevada (LRS) & DB only & State legislators & 1967- \\
\hline & $\begin{array}{l}\text { Public Employees’ Retirement System of Nevada } \\
\text { (PERS) }\end{array}$ & DB only & Full-time state and local government employees & $1947-$ \\
\hline \multicolumn{5}{|c|}{ loter } \\
\hline & Judicial Retirement Plan & DB only & Judges of supreme courts, district courts, and probate courts & 2005- \\
\hline & New Hampshire Retirement System & DB only & $\begin{array}{l}\text { State employees, public school teachers and administrators, } \\
\text { permanent firefighters, and police officers }\end{array}$ & $1967-$ \\
\hline \multicolumn{5}{|c|}{ 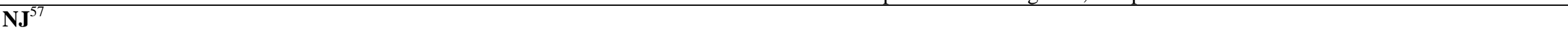 } \\
\hline & Judicial Retirement System (JRS) & DB only & Members of the New Jersey judiciary system & 1973- \\
\hline & $\begin{array}{l}\text { New Jersey Defined Contribution Retirement Program } \\
\text { (DCRP) })^{58}\end{array}$ & Mandatory DC & $\begin{array}{l}\text { State or local officials and certain PERS, TPAF, PFRS, } \\
\text { and SPRS members }\end{array}$ & 2007- \\
\hline & Police and Firemen’s Retirement System (PFRS) & DB only & County and municipal policemen and firemen and state firemen & 1944- \\
\hline & Public Employees’ Retirement System (PERS) & DB only & $\begin{array}{l}\text { Most full-time employees of the state or any county, } \\
\text { municipality, school district, or public agency that do not } \\
\text { participate in another state plan }\end{array}$ & $1955-$ \\
\hline & State Police Retirement System (SPRS) & DB only & Uniformed officers and troopers of the New Jersey State Police & 1965- \\
\hline & Teachers’ Pension and Annuity Fund (TPAF) & DB only & $\begin{array}{l}\text { Most full-time certified teachers or professional staff of public } \\
\text { school systems in the state }\end{array}$ & 1955- \\
\hline
\end{tabular}


Table 1 Primary State Plans: New Mexico to New York

\begin{tabular}{|c|c|c|c|c|}
\hline State & Plan Name & Primary Plan Options & Type of Employees Covered & Eligibility \\
\hline \multicolumn{5}{|c|}{ T } \\
\hline & \multirow{3}{*}{\multicolumn{4}{|c|}{$\begin{array}{l}\text { New Mexico Educational Retirement Board (ERB) } \\
\text { New Mexico Educational Employees’ Retirement } \\
\text { System (EERS) }\end{array}$}} \\
\hline & & & & \\
\hline & & & & \\
\hline & Alternate Retirement Plan (ARP) & DC choice & $\begin{array}{l}\text { Faculty and professional employees of the state's higher } \\
\text { education institutions and community colleges }\end{array}$ & 1991- \\
\hline & Defined Benefit Plan & DB only, DB choice & $\begin{array}{l}\text { Certified teachers and other employees of educational } \\
\text { and technical-vocational institutions and junior colleges }\end{array}$ & $1957-$ \\
\hline & \multicolumn{4}{|l|}{ New Mexico Public Employees’ Retirement } \\
\hline & \multicolumn{4}{|l|}{ Association (PERA) } \\
\hline & Judicial Retirement System (JRS) & DB only & Judges and justices & $*$ \\
\hline & Magistrate Retirement System (MRS) & DB only & Magistrates & $*$ \\
\hline & Public Employees Retirement System (PERS) & DB only & $\begin{array}{l}\text { General state and municipal employees, state policemen, } \\
\text { and other hazardous duty employees, municipal policemen } \\
\text { and firemen, and employees of the state legislature }\end{array}$ & 1947- \\
\hline & Volunteer Firefighter Retirement System (VFRS) & DB only & Volunteer non-salaried firefighters & 1983- \\
\hline \multicolumn{5}{|l|}{$\mathbf{N Y}^{60}$} \\
\hline \multicolumn{5}{|c|}{ New York State and Local Retirement System } \\
\hline & $\begin{array}{l}\text { New York State and Local Employees’ Retirement } \\
\text { System (ERS) }\end{array}$ & DB only & $\begin{array}{l}\text { State and local employees in non-teaching positions, including } \\
\text { uniformed services personnel }\end{array}$ & 1921- \\
\hline & $\begin{array}{l}\text { New York State and Local Police and Fire } \\
\text { Retirement System (PFRS) }\end{array}$ & DB only & $\begin{array}{l}\text { Police officers and firefighters who work for participating } \\
\text { employers }\end{array}$ & 1966- \\
\hline & $\begin{array}{l}\text { New York State Teachers Retirement System } \\
\text { (NYSTRS) }\end{array}$ & DB only & Most New York State public school teachers and administrators & $1921-$ \\
\hline
\end{tabular}


Table 1 Primary State Plans: North Carolina to North Dakota

\begin{tabular}{|c|c|c|c|c|}
\hline State & Plan Name & Primary Plan Options & Type of Employees Covered & Eligibility \\
\hline \multicolumn{5}{|c|}{ 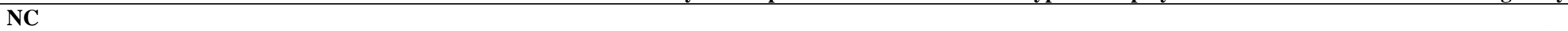 } \\
\hline & Consolidated Judicial Retirement System (CJRS) & DB only & $\begin{array}{l}\text { Elected judges and justices, district attorneys, clerks, and public } \\
\text { defenders }\end{array}$ & $1985-{ }^{61}$ \\
\hline & Firemen's and Rescue Squad Workers’ Pension Fund & DB only & Certified firemen and rescue squad workers & 1959- \\
\hline & Legislative Retirement System (LRS) & DB only & Members of the General Assembly & 1983- \\
\hline & $\begin{array}{l}\text { Local Governmental Employees’ Retirement System } \\
\text { (LGERS) }\end{array}$ & DB only & $\begin{array}{l}\text { Employees of the cities, towns, counties, boards, commissions, } \\
\text { and other entities of local government }\end{array}$ & $1945-62$ \\
\hline & North Carolina National Guard Pension Fund & DB only & National Guardsmen & $1979-{ }^{63}$ \\
\hline & $\begin{array}{l}\text { Teachers’ and State Employees’ Retirement System } \\
\text { (TSERS) }\end{array}$ & DB only, DB choice ${ }^{\mathbf{D}}$ & $\begin{array}{l}\text { Full-time teachers and state employees in public schools, } \\
\text { universities, departments, institutions, and state agencies }\end{array}$ & 1941- \\
\hline & Optional Retirement Program ${ }^{64}$ & DC choice & $\begin{array}{l}\text { Faculty and administrators with faculty rank in institutions of the } \\
\text { UNC System }\end{array}$ & $1971-$ \\
\hline \multicolumn{5}{|c|}{ e } \\
\hline \multicolumn{5}{|c|}{ North Dakota Public Employees Retirement System ${ }^{65}$} \\
\hline & $\begin{array}{l}\text { North Dakota Highway Patrolman’s Retirement } \\
\text { System (NDHPRS) }\end{array}$ & DB only & $\begin{array}{l}\text { Substantially all sworn officers of the North Dakota Highway } \\
\text { Patrol }\end{array}$ & 1949- \\
\hline & $\begin{array}{l}\text { North Dakota Defined Contribution Retirement } \\
\text { Plan }\end{array}$ & DC choice & State employees in unclassified positions & $2000-$ \\
\hline & $\begin{array}{l}\text { North Dakota Public Employees’ Retirement } \\
\text { System (PERS) }\end{array}$ & DB only, DB choice ${ }^{\mathbf{D}}$ & $\begin{array}{l}\text { Most employees of the state, its agencies, and various political } \\
\text { subdivisions; certain judges, the National Guard Security } \\
\text { officers and Firefighters, local peace officers, and corrections } \\
\text { officers }\end{array}$ & 1966- \\
\hline & $\begin{array}{l}\text { Retirement Plan for the Employees of Job } \\
\text { Service North Dakota (JSND) }{ }^{*} \mathrm{C}\end{array}$ & DB only & Employees of Job Service North Dakota & $1961-1980$ \\
\hline & North Dakota Teachers’ Fund for Retirement (TFFR) & DB only & All North Dakota public teachers and certain non-public teachers & 1913- \\
\hline & $\begin{array}{l}\text { Teachers’ Insurance and Annuity Association } \\
\text { (TIAA-CREF) }\end{array}$ & DC only & Faculty and administrative staff in higher education & * \\
\hline
\end{tabular}


Table 1 Primary State Plans: Ohio

\begin{tabular}{|c|c|c|c|c|}
\hline State & Plan Name & Primary Plan Options & Type of Employees Covered & Eligibility \\
\hline \multicolumn{5}{|l|}{$\mathbf{O H}$} \\
\hline & Alternative Retirement Plan (ARP) ${ }^{67}$ & DC choice & $\begin{array}{l}\text { Higher education faculty and staff, and certain unclassified civil } \\
\text { service employees }\end{array}$ & 1997- \\
\hline & Ohio Police and Fire Pension Fund (OP\&F) & DB only & $\begin{array}{l}\text { Full-time municipal police officers; full-time state and municipal } \\
\text { firefighters }\end{array}$ & 1967- \\
\hline & \multicolumn{4}{|l|}{$\begin{array}{l}\text { Ohio Public Employees Retirement System } \\
\text { (OPERS) }^{68}\end{array}$} \\
\hline & Traditional Pension Plan & DB choice ${ }^{D}$ & $\begin{array}{l}\text { Public employees of Ohio not covered by another state } \\
\text { retirement system or by the Cincinnati Retirement System }\end{array}$ & 1935- \\
\hline & Member-Directed Plan & DC choice & $\begin{array}{l}\text { Public employees of Ohio not covered by another state } \\
\text { retirement system or by the Cincinnati Retirement System }\end{array}$ & 2003- \\
\hline & Combined Plan & Hybrid choice & $\begin{array}{l}\text { Public employees of Ohio not covered by another state } \\
\text { retirement system or by the Cincinnati Retirement System }\end{array}$ & 2003- \\
\hline & Ohio School Employees Retirement System (SERS) & DB only & $\begin{array}{l}\text { Non-teaching employees of public schools and certain public } \\
\text { institutions of higher education }\end{array}$ & 1937- \\
\hline & State Highway Patrol Retirement System (SHPRS) & DB only & Members of the Ohio State Highway Patrol & 1944- \\
\hline & \multicolumn{4}{|l|}{ State Teachers Retirement System of Ohio (STRS) ${ }^{69}$} \\
\hline & Defined Benefit Plan & DB choice $^{\mathrm{D}}$ & $\begin{array}{l}\text { Teachers and faculty of public education boards, state-supported } \\
\text { colleges and universities, and the state of Ohio and its political } \\
\text { subdivisions }\end{array}$ & 1919- \\
\hline & Defined Contribution Plan & DC choice & $\begin{array}{l}\text { Teachers and faculty of public education boards, state-supported } \\
\text { colleges and universities, and the state of Ohio and its political } \\
\text { subdivisions }\end{array}$ & 2001- \\
\hline & Combined Plan & Hybrid choice & $\begin{array}{l}\text { Teachers and faculty of public education boards, state-supported } \\
\text { colleges and universities, and the state of Ohio and its political } \\
\text { subdivisions }\end{array}$ & 2001- \\
\hline
\end{tabular}


Table 1 Primary State Plans: Oklahoma to Oregon

\begin{tabular}{|c|c|c|c|c|}
\hline State & Plan Name & Primary Plan Options & Type of Employees Covered & Eligibility \\
\hline \multicolumn{5}{|l|}{$\mathbf{O K}^{70}$} \\
\hline & $\begin{array}{l}\text { Oklahoma Firefighters Pension and Retirement } \\
\text { System (OFPRS) }\end{array}$ & DB only & Municipal firefighters & $1981-$ \\
\hline & $\begin{array}{l}\text { Oklahoma Law Enforcement Retirement System } \\
\text { (OLERS) }\end{array}$ & DB only & Qualified law enforcement officers & 1947- \\
\hline & $\begin{array}{l}\text { Oklahoma Police Pension and Retirement System } \\
\text { (OPPRS) }\end{array}$ & DB only & Qualified police officers of participating municipalities & $1981-$ \\
\hline & \multicolumn{4}{|l|}{$\begin{array}{l}\text { Oklahoma Public Employees Retirement System } \\
\text { (OPERS) }\end{array}$} \\
\hline & $\begin{array}{l}\text { Oklahoma Public Employees Retirement System } \\
\text { (OPERS) }\end{array}$ & DB only & $\begin{array}{l}\text { Most employees of the state not covered by another plan and } \\
\text { employees of participating counties and local agencies }\end{array}$ & $1964-$ \\
\hline & $\begin{array}{l}\text { Uniform Retirement System for Justices and Judges } \\
\text { (URSJJ) }\end{array}$ & DB only & Judges and justices & 1968- \\
\hline & Teachers Insurance and Annuity Association (TIAA) & DC choice & Certain employees in higher education institutions & $*$ \\
\hline & Teachers’ Retirement System of Oklahoma & DB only, DB choice ${ }^{\mathbf{D}}$ & $\begin{array}{l}\text { Public education employees in the common schools, career } \\
\text { technology centers, colleges and universities, and other } \\
\text { educational agencies }\end{array}$ & 1943- \\
\hline \multicolumn{5}{|c|}{ 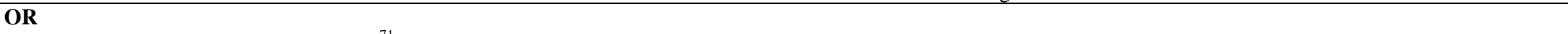 } \\
\hline & Optional Retirement Plan (ORP) $)^{71}$ & DC choice & Unclassified faculty and staff of the Oregon University System & 1996- \\
\hline & $\begin{array}{l}\text { Oregon Health and Science University Pension Plan } \\
(\mathrm{UPP})^{72}\end{array}$ & DC choice & Employees of Oregon Health and Science University & 1996- \\
\hline & \multicolumn{4}{|l|}{$\begin{array}{l}\text { Oregon Public Employees Retirement System } \\
(\mathrm{PERS})^{73}\end{array}$} \\
\hline & Tier 1 Defined Benefit Plan *C & Mandatory DB & $\begin{array}{l}\text { Employees of the State, school districts, community colleges, } \\
\text { and political subdivisions }\end{array}$ & 1967-1995 \\
\hline & Tier 2 Defined Benefit Plan *C & Mandatory DB & $\begin{array}{l}\text { Employees of the State, school districts, community colleges, } \\
\text { and political subdivisions }\end{array}$ & $1996-2003$ \\
\hline & Oregon Public Service Retirement Plan (OPSRP) & $\begin{array}{l}\text { Mandatory Hybrid, } \\
\text { Hybrid choice }^{\mathbf{D}}\end{array}$ & $\begin{array}{l}\text { Employees of the State, school districts, community colleges, } \\
\text { and political subdivisions }\end{array}$ & 2003- \\
\hline & Pension Program & Mandatory DB & $\begin{array}{l}\text { Employees of the State, school districts, community colleges, } \\
\text { and political subdivisions }\end{array}$ & 2003- \\
\hline & Individual Account Program (IAP) & Mandatory DC & $\begin{array}{l}\text { Employees of the State, school districts, community colleges, } \\
\text { and political subdivisions }\end{array}$ & 2003- \\
\hline
\end{tabular}


Table 1 Primary State Plans: Pennsylvania to South Carolina

\begin{tabular}{|c|c|c|c|c|}
\hline State & Plan Name & Primary Plan Options & Type of Employees Covered & Eligibility \\
\hline \multicolumn{5}{|c|}{ 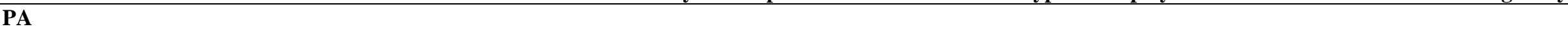 } \\
\hline & $\begin{array}{l}\text { Pennsylvania Public School Employees’ Retirement } \\
\text { System (PSERS) }\end{array}$ & DB only & Public school employees of the Commonwealth & $1917-$ \\
\hline & $\begin{array}{l}\text { Pennsylvania State Employees’ Retirement System } \\
\text { (SERS) }\end{array}$ & DB only & $\begin{array}{l}\text { Employees of the Commonwealth and certain other public } \\
\text { agencies }\end{array}$ & 1923- \\
\hline \multicolumn{5}{|c|}{ 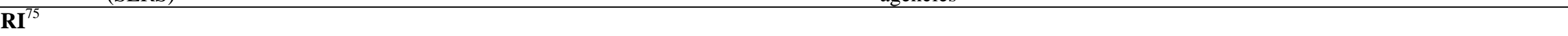 } \\
\hline & \multicolumn{4}{|l|}{$\begin{array}{l}\text { Employees’ Retirement System of Rhode Island } \\
\text { (ERSRI) }\end{array}$} \\
\hline & \multicolumn{4}{|l|}{ Employees’ Retirement System (ERS) } \\
\hline & Defined Benefit $* C$ & DB only & Most state employees & 1936-2012 \\
\hline & Hybrid & Mandatory Hybrid & Most state employees & 2012- \\
\hline & Judicial Retirement Benefits Trust (JRBT) & DB only & Judges and justices & 1989- \\
\hline \multicolumn{5}{|c|}{ Municipal Employees’ Retirement System (MERS) } \\
\hline & Defined Benefit $* C$ & DB only & $\begin{array}{l}\text { Employees of municipalities, housing authorities, water and } \\
\text { Sewer districts, and certain municipal police and fire persons }\end{array}$ & $1951-2012$ \\
\hline & Hybrid & Mandatory Hybrid & $\begin{array}{l}\text { Employees of municipalities, housing authorities, water and } \\
\text { Sewer districts, and certain municipal police and fire persons }\end{array}$ & 2012- \\
\hline & State Police Retirement Benefits Trust (SPRBT) & DB only & State police and superintendents & 1987- \\
\hline & Higher Education Defined Contribution Plans & Mandatory DC & $\begin{array}{l}\text { Certain faculty and staff of the University of Rhode Island, } \\
\text { Rhode Island College, and the Community College of Rhode } \\
\text { Island }\end{array}$ & $*$ \\
\hline \multicolumn{5}{|c|}{ ( } \\
\hline \multicolumn{5}{|c|}{ South Carolina Retirement Systems } \\
\hline & National Guard Retirement System (NGRS) & DB only & National Guard members who served in South Carolina & 1975- \\
\hline & $\begin{array}{l}\text { Retirement System for Judges and Solicitors of the } \\
\text { State of South Carolina (JSRS) }\end{array}$ & DB only & Judges, solicitors, and circuit public defenders of the State & 1979- \\
\hline & $\begin{array}{l}\text { Retirement System for Members of the General } \\
\text { Assembly of the State of South Carolina (GARS) }\end{array}$ & DB only & Members of the South Carolina General Assembly & 1966- \\
\hline & $\begin{array}{l}\text { South Carolina Police Officers’ Retirement System } \\
\text { (PORS) }\end{array}$ & DB only & $\begin{array}{l}\text { State and local police officers and fire fighters, peace officers, } \\
\text { coroners, probate judges, and magistrates }\end{array}$ & $1962-$ \\
\hline & South Carolina Retirement System (SCRS) & DB choice ${ }^{\mathrm{D}}$ & Teachers and employees of the State and political subdivisions & 1945- \\
\hline & State Optional Retirement Program (State ORP) & DC choice & $\begin{array}{l}\text { Newly hired state, public school, and higher education } \\
\text { employees }\end{array}$ & 2002- \\
\hline
\end{tabular}


Table 1 Primary State Plans: South Dakota to Texas

\begin{tabular}{|c|c|c|c|c|}
\hline \multirow{2}{*}{ State } & Plan Name & Primary Plan Options & Type of Employees Covered & Eligibility \\
\hline & South Dakota Retirement System (SDRS) ${ }^{78}$ & DB only & Employees of the State and its political subdivisions & 1974- \\
\hline TN & Optional Retirement Plan (ORP) & DC choice & $\begin{array}{l}\text { Certain faculty and staff of the Tennessee Board of Regents } \\
\text { institutions and the University of Tennessee system }\end{array}$ & 1978- \\
\hline & $\begin{array}{l}\text { Tennessee Consolidated Retirement System (TCRS) } \\
\text { Political Subdivision Pension Plan (PSPP) } \\
\text { State Employees, Teachers, and Higher Education } \\
\text { Employees Pension Plan (SETHEEPP) }\end{array}$ & $\begin{array}{c}\text { DB only } \\
\text { DB only, DB choice }\end{array}$ & $\begin{array}{l}\text { Public employees of participating political subdivisions } \\
\text { Employees of the state, teachers with Local Education Agencies } \\
\text { (LEAs) and higher education employees }\end{array}$ & $\begin{array}{l}1972- \\
1972-\end{array}$ \\
\hline $\mathbf{T X}^{80}$ & $\begin{array}{l}\text { Employees Retirement System of Texas (ERS) } \\
\text { Employees Retirement System of Texas Plan } \\
\text { (ERS Plan) } \\
\text { Judicial Retirement System of Texas (JRS) }\end{array}$ & DB only & State employees and officers & 1947- \\
\hline & $\begin{array}{l}\text { Plan One (JRS1) *C } \\
\text { Plan Two (JRS2) } \\
\text { Law Enforcement and Custodial Officer } \\
\text { Supplemental Retirement Plan (LECOS) }\end{array}$ & $\begin{array}{l}\text { DB only } \\
\text { DB only } \\
\text { DB only }\end{array}$ & $\begin{array}{l}\text { Judges } \\
\text { Judges } \\
\text { Certain law enforcement officers and certified custodial } \\
\quad \text { Officers }\end{array}$ & $\begin{array}{l}1949-1985 \\
1985- \\
1979-\end{array}$ \\
\hline & Optional Retirement Program (ORP) & DC choice & $\begin{array}{l}\text { Full-time faculty, librarians, and certain professionals and } \\
\text { administrators employed in public higher education }\end{array}$ & 1967- \\
\hline & Texas County \& District Retirement System (TCDRS) & Mandatory Cash Balance & $\begin{array}{l}\text { County public service officers, emergency service providers, } \\
\text { nurses, county judges, and commissioners }\end{array}$ & 1967- \\
\hline & $\begin{array}{l}\text { Texas Emergency Services Retirement System } \\
\text { (TESRS) }^{81}\end{array}$ & DB only & Volunteer municipal fire fighters and EMS personnel & 1977- \\
\hline & Texas Municipal Retirement System (TMRS) & Mandatory Cash Balance & Employees of participating municipalities & 1947- \\
\hline & Teacher Retirement System of Texas (TRS) & DB only, DB choice ${ }^{\mathbf{D}}$ & Employees of public education institutions & 1937- \\
\hline
\end{tabular}


Table 1 Primary State Plans: Utah

\begin{tabular}{|c|c|c|c|c|}
\hline State & Plan Name & Primary Plan Options & Type of Employees Covered & Eligibility \\
\hline \multicolumn{5}{|l|}{ UT } \\
\hline & $\begin{array}{l}\text { Teachers Insurance and Annuity Association-College } \\
\text { Retirement Equities Fund (TIAA-CREF) and } \\
\text { Fidelity Investments }\end{array}$ & Mandatory DC & Faculty and staff of state colleges and universities & $*$ \\
\hline & \multicolumn{4}{|l|}{ Utah Retirement Systems (URS) } \\
\hline & Firefighters Retirement System ${ }^{*} \mathrm{C}$ & DB only & State and local govt. employees directly involved in fire fighting & 1970s-2011 \\
\hline & Judges Retirement System & DB only & Judges and justices & 1997- \\
\hline & Public Safety Retirement System *C & DB only & $\begin{array}{l}\text { State and local govt. employees directly involved in law } \\
\text { enforcement }\end{array}$ & 1970s-2011 \\
\hline & \multicolumn{4}{|l|}{$\begin{array}{l}\text { Tier } 2 \text { Public Safety and Firefighters Retirement } \\
\text { System }^{82}\end{array}$} \\
\hline & Tier 2 Hybrid Retirement System & Hybrid choice $^{\mathrm{D}}$ & $\begin{array}{l}\text { State and local govt. employees directly involved in law } \\
\text { enforcement or fire fighting }\end{array}$ & 2011- \\
\hline & Tier 2 Defined Contribution Plan & DC choice & $\begin{array}{l}\text { State and local govt. employees directly involved in law } \\
\text { enforcement or fire fighting }\end{array}$ & 2011- \\
\hline & $\begin{array}{l}\text { Tier } 1 \text { Public Employees Contributory } \\
\quad \text { Retirement System }{ }^{*} \mathrm{C}\end{array}$ & DB only & $\begin{array}{l}\text { Public employees and public education employees of Utah and } \\
\text { its political subdivisions }\end{array}$ & $1967-2011^{83}$ \\
\hline & \multicolumn{4}{|l|}{$\begin{array}{l}\text { Tier } 2 \text { Public Employees Contributory Retirement } \\
\text { System }^{84}\end{array}$} \\
\hline & Tier 2 Hybrid Retirement System & Hybrid choice $^{\mathrm{D}}$ & $\begin{array}{l}\text { Public employees and public education employees of Utah and } \\
\text { its political subdivisions }\end{array}$ & 2011- \\
\hline & Tier 2 Defined Contribution Plan & DC choice & $\begin{array}{l}\text { Public employees and public education employees of Utah and } \\
\text { its political subdivisions }\end{array}$ & 2011- \\
\hline & Utah Governors and Legislative Retirement Plan *C & DB only & Governors and legislators & Pre- 2011 \\
\hline
\end{tabular}


Table 1 Primary State Plans: Vermont

\begin{tabular}{|c|c|c|c|c|}
\hline State & Plan Name & Primary Plan Options & Type of Employees Covered & Eligibility \\
\hline \multicolumn{5}{|c|}{ 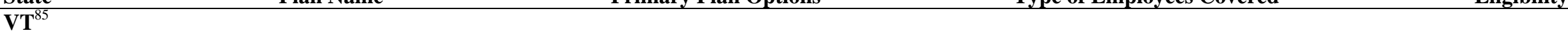 } \\
\hline & $\begin{array}{l}\text { Vermont Municipal Employees’ Defined Contribution } \\
\text { Plan }\end{array}$ & $\mathrm{DC}^{86}$ & Certain groups of employees eligible for VMERS & $2000-$ \\
\hline & $\begin{array}{l}\text { Vermont Municipal Employees’ Retirement System } \\
\text { (VMERS) }\end{array}$ & DB only & School districts and other municipal employees & 1975- \\
\hline & Vermont State Defined Contribution Plan & DC choice & Exempt state employees eligible for VSERS & 1999- \\
\hline & $\begin{array}{l}\text { Vermont State Employees’ Retirement System } \\
\text { (VSERS) }\end{array}$ & DB only, DB choice ${ }^{\mathbf{D}}$ & Substantially all general State employees and State police & 1944- \\
\hline
\end{tabular}


Table 1 Primary State Plans: Virginia

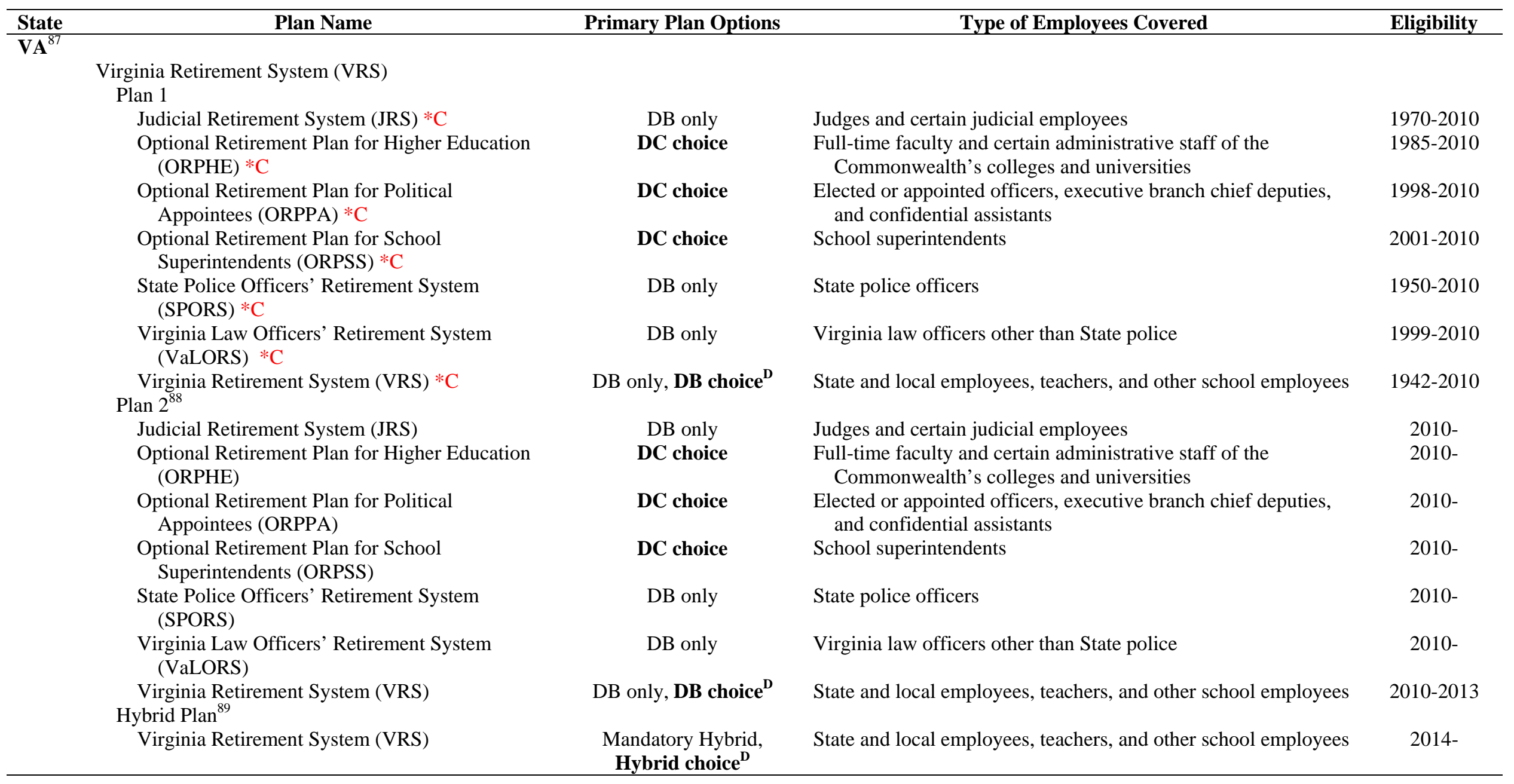


Table 1 Primary State Plans: Washington

\begin{tabular}{|c|c|c|c|c|}
\hline State & Plan Name & Primary Plan Options & Type of Employees Covered & Eligibility \\
\hline \multicolumn{5}{|c|}{ 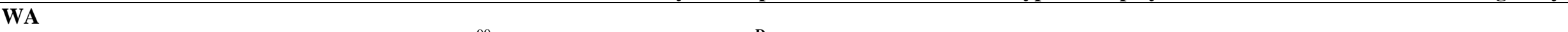 } \\
\hline & Higher Education Retirement Plans (HERP) ${ }^{90}$ & DC choice $^{\mathrm{D}}$ & Certain employees in higher education & $*$ \\
\hline & Volunteer Fire Fighters’ and Reserve Officers’ & DB only & Volunteer fire fighters, emergency workers, and reserve officers & 1945- \\
\hline \multicolumn{5}{|c|}{ Relief and Pension Fund (VFFRPF) } \\
\hline & \multicolumn{4}{|l|}{$\begin{array}{l}\text { Washington Department of Retirement Systems } \\
\text { (WDRS) }\end{array}$} \\
\hline & Judges’ Retirement Fund *C & DB only & Supreme Court, Court of Appeals, and Superior Court judges & 1937-1971 \\
\hline & Judicial Retirement System ${ }^{*} \mathrm{C}$ & DB only & Supreme Court, Court of Appeals, and Superior Court judges & 1971-1988 \\
\hline \multicolumn{5}{|c|}{ Retirement System (LEOFF) } \\
\hline & Plan $1 * \mathrm{C}$ & DB only & $\begin{array}{l}\text { Full-time local law enforcement commissioned officers, } \\
\text { firefighters, and eligible emergency medical technicians }\end{array}$ & $1970-1977$ \\
\hline & Plan 2 & DB only & $\begin{array}{l}\text { Full-time local law enforcement commissioned officers, } \\
\text { firefighters, and eligible emergency medical technicians }\end{array}$ & 1977- \\
\hline \multicolumn{5}{|c|}{ Public Employees’ Retirement System (PERS) ${ }^{91}$} \\
\hline & Plan $1 * \mathrm{C}$ & Mandatory DB & $\begin{array}{l}\text { State and local employees, elected officials, and employees } \\
\text { of courts, legislative groups, colleges and universities }\end{array}$ & $1947-1977$ \\
\hline & Plan 3 & Hybrid choice $^{D}$ & $\begin{array}{l}\text { State and local employees, elected officials, and employees } \\
\text { of courts, legislative groups, colleges and universities }\end{array}$ & 2002- \\
\hline \multicolumn{5}{|c|}{$\begin{array}{l}\text { Public Safety Employees’ Retirement System } \\
\text { (PSERS) }\end{array}$} \\
\hline & Plan 2 & DB only & $\begin{array}{l}\text { Corrections officers and certain employees of the Gambling } \\
\text { Commission, Liquor Control Board, Parks and Recreation } \\
\text { Commission, Washington State Patrol, and Department of } \\
\text { Natural Resources }\end{array}$ & 2006- \\
\hline \multicolumn{5}{|c|}{ School Employees’ Retirement System (SERS) ${ }^{92}$} \\
\hline & Plan 2 & DB choice & $\begin{array}{l}\text { Classified employees of school districts and educational service } \\
\text { districts }\end{array}$ & $2000-$ \\
\hline & Plan 3 & Hybrid choice $^{D}$ & $\begin{array}{l}\text { Classified employees of school districts and educational service } \\
\text { districts }\end{array}$ & 2000- \\
\hline
\end{tabular}


Table 1 Primary State Plans: Washington (continued) to Wisconsin

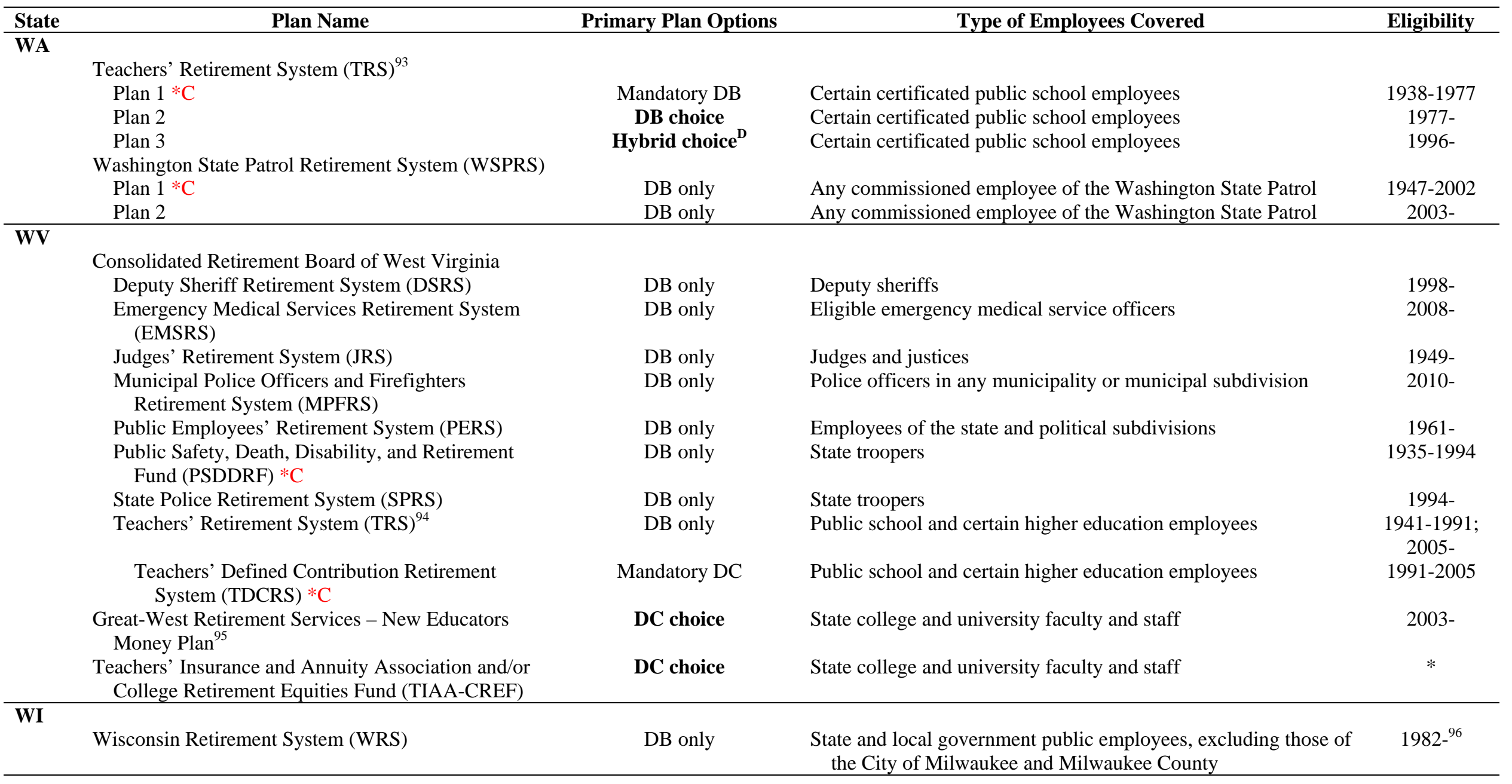


Table 1 Primary State Plans: Wyoming

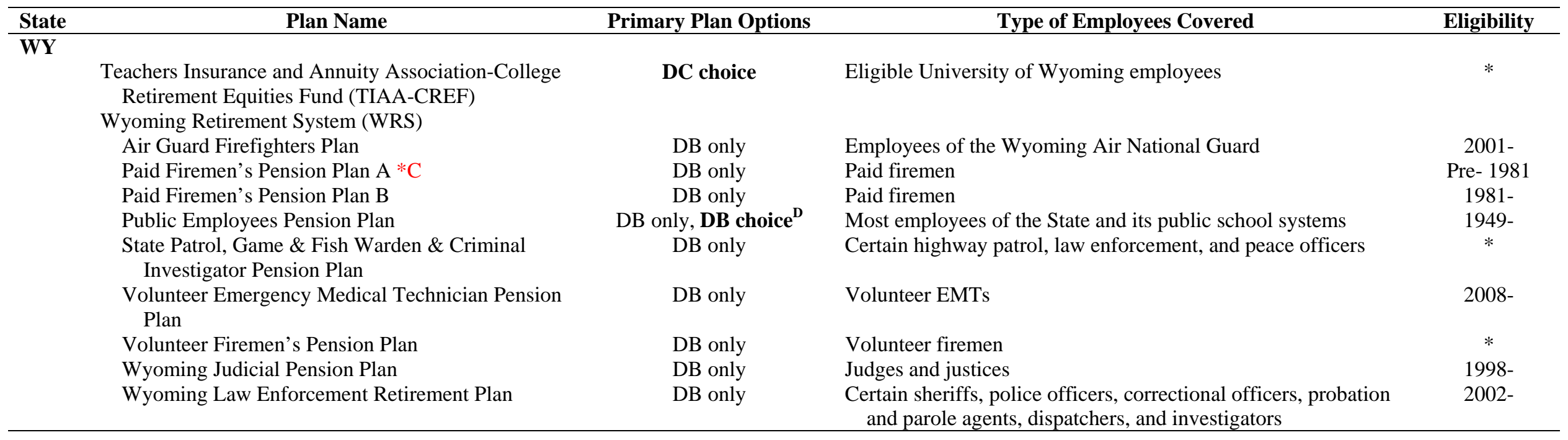




\section{Table 2: Targeted DC and Hybrid Plans}

For the survey, we targeted large state primary DC and hybrid plans and newly introduced plans that are expected to cover a substantial number of members in the future. All plans were opened prior to June 2012. Plans that have active members but are closed to new employees are denoted with a ${ }^{*} \mathrm{C}$ following their name. The tables include the year the plan was enacted for new hires, approximate current active members and approximate plan assets. Panel A presents DC and hybrid plans that are mandatory plans for their employees. Panel B presents DC and hybrid plans that are offered as part of an employee's choice set.

\section{Panel A. Mandatory DC and Hybrid Plans}

Mandatory DC

Alaska PERS-DCR

Alaska TRS-DCR

Nebraska County Employees Defined Contribution Plan *C

Nebraska State Employees Defined Contribution Plan *C

State of Michigan Defined Contribution Plan

Mandatory Hybrid

Georgia ERS-GSEPS

Indiana PERF - ASA

Indiana STRF - ASA

Michigan - MPSERS-PPP

Oregon PERS - IAP
Date Enacted

\begin{tabular}{crr}
2006 & 11,182 & $\$ 183,702$ \\
2006 & 2,738 & $\$ 83,972$ \\
1966 & 1,982 & $\$ 179,370$ \\
1964 & 5,224 & $\$ 706,461$ \\
1997 & 26,822 & $\$ 1,555,608$ \\
\hline Subtotal Mandatory DC & 47,948 & $\$ 2,709,113$ \\
\hline & & \\
2009 & 11,093 & $\$ 13,462$ \\
1997 & 147,933 & $\$ 2,805,023$ \\
1997 & 71,343 & $\$ 3,094,797$ \\
2010 & 9,424 & $\$ 1,423$ \\
2003 & 183,349 & $\$ 4,036,837$ \\
\hline \hline Subtotal Mandatory Hybrid & 423,142 & $\$ 9,951,542$ \\
\hline \hline
\end{tabular}

Approx. Approx. Assets

Actives $^{1} \quad$ (in Thousands) ${ }^{1}$

$11,182 \quad \$ 183,702$

$\$ 706,461$

$\$ 1,555,608$
$47,948 \quad \$ 2,709,113$

$471,090 \quad \$ 12,660,655$ 


\section{Panel B. DC and Hybrid Offered as a Choice Set}

\author{
Primary DC Plan Choice \\ Colorado PERAChoice \\ FRS Investment Plan ${ }^{3}$ \\ Illinois SURS Self-Managed Plan \\ Montana PERS-DCRP \\ Ohio PERS - Member Directed Plan \\ Ohio STRS - Defined Contribution Plan ${ }^{3}$ \\ South Carolina - ORP \\ Utah - Tier 2 Defined Contribution Plan ${ }^{3}$ \\ Primary Hybrid Plan Choice ${ }^{2}$ \\ FRS Investment Plan Hybrid Option ${ }^{3}$ \\ Ohio PERS - Combined Plan \\ Ohio STRS - Combined Plan ${ }^{3}$ \\ Utah - Tier 2 Hybrid Retirement System ${ }^{3}$ \\ Washington PERS - Plan 3 \\ Washington SERS - Plan 3 \\ Washington TRS -Plan 3
}

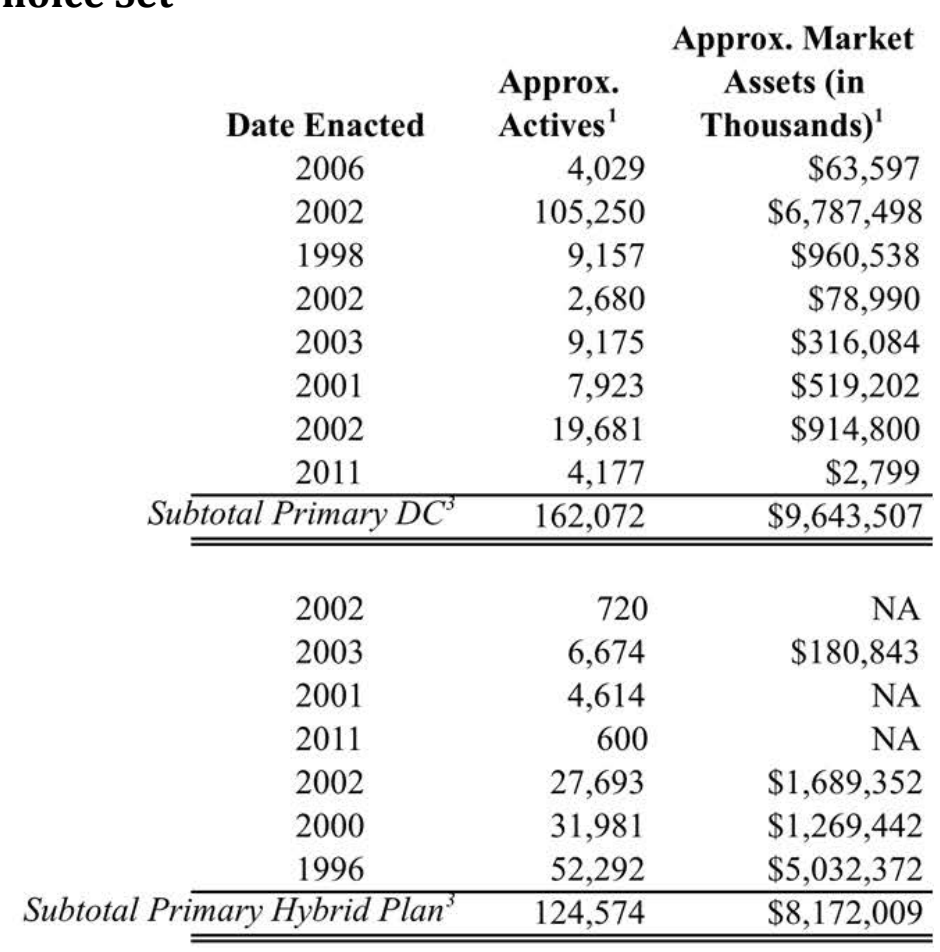

Total for Choice DC and Hybrid Plans

286,646

$17,815,516$

\begin{tabular}{ccrr} 
& 1931 & 54,977 & $\$ 12,487,105$ \\
& 1970 & 540,701 & $\$ 126,579,720$ \\
Plans & 1941,1998 & 66,842 & $\$ 14,274,003$ \\
& 1945 & 28,659 & $\$ 3,942,108$ \\
1935 & 333,340 & $\$ 61,692,654$ \\
1919 & 173,283 & $\$ 63,116,710$ \\
1945 & 196,228 & $\$ 22,395,029$ \\
1977 & 119,826 & $\$ 20,098,636$ \\
2000 & 20,358 & $\$ 2,746,456$ \\
1977 & 9,442 & $\$ 6,839,903$ \\
\hline \multirow{4}{*}{ Subtotal Primary DB Plan } & $1,543,656$ & $\$ 334,172,324$ \\
\hline \hline & & \\
& & $\mathbf{1 , 8 3 0 , 3 0 2}$ & $\mathbf{\$ 3 5 1 , 9 8 7 , 8 4 0}$
\end{tabular}

\section{Primary DB Plan Choice}

Colorado PERA

Florida FRS Pension Plan

Illinois SURS Traditional and Portable Benefit Option Plans

Montana PERS-DBRP

Ohio PERS Traditional Plan

Ohio STRS - Defined Benefit Plan

South Carolina SCRS

Washington PERS Plan 2

Washington SERS Plan 2

Washington TRS Plan 2

\section{Total For All Primary Plans with Choice}

$1,830,302 \quad \$ 351,987,840$

1 The dates of the actives and asset variables reported in the tables range from 7/1/2010 to 12/31/2011. The majority of the actives/assets data come from state Comprehensive Annual Financial Reports (CAFRs), plan CAFRs and plan Actuarial Valuations. For the DC assets, we used the P\&I Research Center's Plan Sponsor data as a check (http://researchcenter.pionline.com/rankings/plan-sponsors/overviewcontribution/?q=[2895_0(eq)P]). For a small number of missing actives values, we used the survey responses from the National Public Pension Plan Financial Education Survey. For the DB plans, we used data from Boston College's Public Plans Database (PPD) for asset values of plans that were not in our survey and as a check for reasonableness for our self-collected values. To maintain the anonymity of plans in the survey, we do not report the date the data was obtained or the source for each plan.

2 The hybrid assets pertain only to those in the DC portion of the plan.

3 The FRS system, Ohio STRS and Utah Tier 2 plans report only one asset number that includes assets from both their DC Plans and hybrid plan option. We include that combined number under their DC plans and place a NA for the hybrid options. As a result, the total for all the DC plans will overestimate the asset value of this category and the hybrid plans total will underestimate the hybrid value. The total for all the primary plans combined is correct. 


\section{Table 3: Representation of Survey Sample}

This table provides an overview of the representation of the surveyed sample versus the targeted population. Panel A aggregates the DC and hybrid primary plans and Panel B highlights the DB plans that are offered as part of a choice set.

Panel A: Hybrid and DC Plans: Mandatory Plans and Plans Offered as part of a Choice Set

\begin{tabular}{|c|c|c|c|}
\hline & Number of Plans & $\begin{array}{l}\text { Approx. } \\
\text { Actives }^{1}\end{array}$ & $\begin{array}{l}\text { Approx. } \\
\text { Assets }^{1} \\
\end{array}$ \\
\hline \multicolumn{4}{|l|}{ Mandatory DC and Hybrid Primary Plans } \\
\hline Mandatory DC and Hybrid Plans Surveyed & 8 & 251,814 & $\$ 6,760,836$ \\
\hline Mandatory DC and Hybrid Plans Total & 10 & 471,090 & $\$ 12,660,655$ \\
\hline$\%$ of Total & $80.0 \%$ & $53.5 \%$ & $53.4 \%$ \\
\hline \multicolumn{4}{|l|}{ DC Choice and Hybrid Choice Primary Plans } \\
\hline Primary Plan Choice Plans Surveyed & 13 & 274,109 & $\$ 17,296,314$ \\
\hline Primary Plan Choice Total & 15 & 286,646 & $\$ 17,815,516$ \\
\hline$\%$ of Total & $86.7 \%$ & $95.6 \%$ & $97.1 \%$ \\
\hline \multicolumn{4}{|l|}{ Total DC and Hybrid Primary Plans } \\
\hline Plans Surveyed & 21 & 525,923 & $\$ 24,057,150$ \\
\hline Plans Total & 25 & 757,736 & $\$ 30,476,171$ \\
\hline$\%$ of Total & $84.0 \%$ & $69.4 \%$ & $78.9 \%$ \\
\hline
\end{tabular}

Panel B: DB Plans Offered as part of a Choice Set

\begin{tabular}{|c|c|c|c|}
\hline & Number of Plans & $\begin{array}{l}\text { Approx. } \\
\text { Actives } \\
\end{array}$ & $\begin{array}{l}\text { Approx. } \\
\text { Assets }^{1}\end{array}$ \\
\hline \multicolumn{4}{|l|}{ DB Choice Plans } \\
\hline Primary Plan Choice Plans Surveyed & 9 & $1,370,373$ & $\$ 271,055,616$ \\
\hline Primary Plan Choice Total & 10 & $1,543,656$ & $\$ 334,172,320$ \\
\hline$\%$ of Total & $90.0 \%$ & $88.8 \%$ & $81.1 \%$ \\
\hline
\end{tabular}

\footnotetext{
${ }^{1}$ The total assets and actives reported in the tables are approximations and may be from sources as far back as 2010 . Percentages reported are only guidelines.
} 


\section{Table 4: Plan Features of Plans Surveyed}

This table reports the percentage of plans surveyed that offer specific plan features and whether these features are available to most employees or just new hires. The 'New Hires Only' and 'Most Employees' column sum to the percentage of plans offering the feature (any differences observed are due to rounding).

\begin{tabular}{lcccc}
\hline & $\begin{array}{c}\text { Not } \\
\text { Offered }\end{array}$ & Offered & $\begin{array}{c}\text { New Hires } \\
\text { Only }\end{array}$ & $\begin{array}{c}\text { Most } \\
\text { Employees }\end{array}$ \\
\hline \hline Mandatory DC and Hybrid Primary Plans- Total 8 Plans Surveyed \\
automatic enrollment & $0 \%$ & $100 \%$ & $13 \%$ & $88 \%$ \\
automatic escalation & $75 \%$ & $25 \%$ & $0 \%$ & $25 \%$ \\
match & $13 \%$ & $88 \%$ & $0 \%$ & $88 \%$ \\
default investment & $13 \%$ & $88 \%$ & $0 \%$ & $88 \%$ \\
vesting & $0 \%$ & $100 \%$ & $0 \%$ & $100 \%$ \\
& & & & \\
DC and Hybrid Primary Plans Offered as a Choice Set- Total 13 Plans Surveyed \\
automatic enrollment & $92 \%$ & $8 \%$ & $0 \%$ & $8 \%$ \\
automatic escalation & $77 \%$ & $23 \%$ & $0 \%$ & $23 \%$ \\
match & $62 \%$ & $38 \%$ & $0 \%$ & $38 \%$ \\
default investment & $0 \%$ & $100 \%$ & $38 \%$ & $62 \%$ \\
vesting & $8 \%$ & $92 \%$ & $8 \%$ & $85 \%$ \\
\hline
\end{tabular}




\section{Table 5: Financial Education and Advice Offerings in DC and Hybrid Primary State Plans}

This table ranks financial education and advice offerings based on the actives eligible for each program and displays the percentage of plans offering each provision.

\begin{tabular}{lccc}
\hline DC and Hybrid Primary State Plans & $\begin{array}{c}\text { Number of } \\
\text { Surveyed Plans } \\
\text { that Offer }\end{array}$ & $\begin{array}{c}\text { \% of Plans } \\
\text { Surveyed }\end{array}$ & $\begin{array}{c}\text { \% of Surveyed } \\
\text { Actives Eligible }\end{array}$ \\
\hline Offer Financial Education and/or Advice & 21 & $100 \%$ & $100 \%$ \\
Type of Financial Education/Advice Offered & 21 & $100 \%$ & $100 \%$ \\
Telephone consultations & 20 & $95 \%$ & $98 \%$ \\
Group Seminars & 20 & $95 \%$ & $98 \%$ \\
Periodic Newsletter & 18 & $86 \%$ & $98 \%$ \\
Live Webinars & 19 & $90 \%$ & $97 \%$ \\
New Hire Information Packet & 11 & $52 \%$ & $73 \%$ \\
Third Party Online Financial Advice & 19 & $90 \%$ & $64 \%$ \\
One-on-one in person consultations & 18 & $86 \%$ & $63 \%$ \\
Financial Education Component to Website & 18 & $86 \%$ & $58 \%$ \\
Online Videos & 12 & $57 \%$ & $19 \%$ \\
Targeted E-mails & 6 & $29 \%$ & $7 \%$ \\
Social Media & & & \\
\hline
\end{tabular}




\section{Table 6: Who Develops the Financial Education and Advice Programs?}

This table reports the number of plans that offer each type of educational and advice program by who develops the program. The program can be developed in-house by the plan, outsourced to a third party or developed in conjunction with a third party. The percentages by row sum to 100 percent as they represent the percentage of plans surveyed that offer each specific type of education or advice.

\begin{tabular}{|c|c|c|c|c|c|c|}
\hline Type of Financial Education and Advice Offered & $\begin{array}{l}\text { Number of Plans } \\
\text { Develop In-House }\end{array}$ & $\%$ & $\begin{array}{c}\text { Number of Plans } \\
\text { Develop Through } \\
\text { Third Party }\end{array}$ & $\%$ & $\begin{array}{c}\text { Number of Plans } \\
\text { Developed In-House } \\
\text { and by a Third Party }\end{array}$ & $\%$ \\
\hline Telephone consultations & 9 & $43 \%$ & 2 & $10 \%$ & 10 & $48 \%$ \\
\hline Group Seminars & 10 & $50 \%$ & 1 & $5 \%$ & 9 & $45 \%$ \\
\hline Periodic Newsletter & 8 & $40 \%$ & 1 & $5 \%$ & 11 & $55 \%$ \\
\hline Live Webinars & 7 & $39 \%$ & 6 & $33 \%$ & 5 & $28 \%$ \\
\hline New Hire Information Packet & 8 & $42 \%$ & 0 & $0 \%$ & 11 & $58 \%$ \\
\hline Third Party Online Financial Advice & 0 & $0 \%$ & 4 & $36 \%$ & 7 & $64 \%$ \\
\hline One-on-one in person consultations & 9 & $47 \%$ & 1 & $5 \%$ & 9 & $47 \%$ \\
\hline Financial Education Component to Website & 4 & $22 \%$ & 3 & $17 \%$ & 11 & $61 \%$ \\
\hline Online Videos & 6 & $33 \%$ & 2 & $11 \%$ & 10 & $56 \%$ \\
\hline Targeted E-mails & 7 & $58 \%$ & 1 & $8 \%$ & 4 & $33 \%$ \\
\hline Social Media & 5 & $83 \%$ & 1 & $17 \%$ & 0 & $0 \%$ \\
\hline
\end{tabular}


Table 7: What are the Most Popular Topics Covered By Programs?

Panel A: Ranking of Plan Specific Topics

\begin{tabular}{|c|c|c|c|}
\hline & \multicolumn{3}{|c|}{ Ranking of Plan Specific Topics (\% Based on Plans Reporting Coverage of Plan Specific Topics) } \\
\hline & First & Second & Third \\
\hline Telephone Consultations & Plan Overview $(100 \%)$ & Plan Distribution $(80 \%)$ & Plan Investment Options (75\%) \\
\hline Group Seminars & Plan Overview (100\%) & Plan Investment Options (75\%) & Plan Distribution Options(70\%) \\
\hline Periodic Newsletter & Plan Overview $(94 \%)$ & Plan Investment Options (56\%) & Plan Distribution Options (50\%) \\
\hline Live Webinars & Plan Overview (100\%) & Plan Investment Options $(60 \%)$ & Plan Distribution Options (60\%) \\
\hline New Hire Information Packet & Plan Overview $(94 \%)$ & Plan Investment Options (72\%) & Plan Distribution Options (39\%) \\
\hline Third Party Online Financial Advice & Plan Investment Options (100\%) & Plan Distribution Options (89\%) & Plan Overview (67\%) \\
\hline One-on-one in person consultations & Plan Overview (100\%) & Plan Distribution Options (79\%) & Plan Investment Options (74\%) \\
\hline Financial Education Component to Website & Plan Overview (100\%) & Plan Investment Options (94\%) & Plan Distribution Options (56\%) \\
\hline Online Videos & Plan Overview (100\%) & Plan Investment Options ( $80 \%)$ & Plan Distribution Options (73\%) \\
\hline Targeted E-mails & Plan Overview (100\%) & Plan Investment Options ( $80 \%)$ & Plan Distribution Options (60\%) \\
\hline Social Media & Plan Overview (100\%) & Plan Distribution (100\%) & Plan Investment Options (50\%) \\
\hline
\end{tabular}




\section{Panel B: Ranking of General Topics}

\begin{tabular}{|c|c|c|c|}
\hline & \multicolumn{3}{|c|}{ Ranking of General Topics (\% of Plans Reporting Coverage of General Topics) } \\
\hline & First & Second & Third \\
\hline Telephone Consultations & Retirement Planning $(100 \%)$ & Diversification $(53 \%)$ & Overview of Asset Types (53\%) \\
\hline Group Seminars & Retirement Planning $(100 \%)$ & Diversification $(74 \%)$ & Overview of Asset Types (74\%) \\
\hline Periodic Newsletter & Retirement Planning (100\%) & Overview of asset types $(67 \%)$ & $\begin{array}{l}\text { Diversification }(60 \%) \text {, Basic Investing } \\
\text { Principles }(60 \%)\end{array}$ \\
\hline Live Webinars & Retirement Planning (100\%) & Diversification $(82 \%)$ & Basic Investing Principles (73\%) \\
\hline New Hire Information Packet & Retirement Planning (100\%) & Overview of Asset Types (77\%) & Basic Investing Principles (59\%) \\
\hline Third Party Online Financial Advice & Basic Investing Principles (100\%) & Diversification $(100 \%)$ & $\begin{array}{l}\text { Overview of Asset Types (78\%), Reitrement } \\
\text { Planning }(78 \%)\end{array}$ \\
\hline One-on-one in person consultations & Retirement Planning (100\%) & Overview of Asset Types (72\%) & Diversification $(67 \%)$ \\
\hline Financial Education Component to Website & Retirement Planning (93\%) & Diversification $(80 \%)$ & Overview of Asset Types ( $80 \%)$ \\
\hline Online Videos & Retirement Planning (100\%) & Basic Investing Principals ( $83 \%$ ) & $\begin{array}{l}\text { Diversification ( } 83 \%) \text {, Overview of Asset } \\
\text { Types }(83 \%)\end{array}$ \\
\hline Targeted E-mails & Retirement Planning (100\%) & Diversification $(33 \%)$ & Overview of Asset Types (33\%) \\
\hline Social Media & Retirement Planning $(100 \%)$ & $\begin{array}{r}\text { Report covering Compound Inter } \\
\text { Asset Ty }\end{array}$ & $\begin{array}{l}\text { ng, Debt Management, Inflation, Overview of } \\
\text { ent Planning Equally }\end{array}$ \\
\hline
\end{tabular}




\section{Table 8: How is Success Measured?}

This table reports how plans measure success in their financial education and advice programs. The percentage is based on the number of plans who report measuring success.

\begin{tabular}{lc}
\hline Method for Measuring Success & $\begin{array}{c}\text { Percentage of DC and Hybrid Plans } \\
\text { that Report Measuring Success (Total: } \\
\text { 21 Plans) }\end{array}$ \\
\hline \hline Administer surveys to participants & $88 \%$ \\
Track attendance & $88 \%$ \\
Count unique visits to website or online education module & $59 \%$ \\
Collect ratings from participants & $47 \%$ \\
Track default rate & $41 \%$ \\
Follow participant investment behavior post education & $35 \%$ \\
Receive assessment from independent consultant & $12 \%$ \\
Perform experimental field studies & $12 \%$ \\
\hline
\end{tabular}


Figure 1: Type of Financial Education Topics Covered Within Each Type of Educational/Advice Program

This figure shows the type of topics covered by different plans within each type of financial education and advice program.

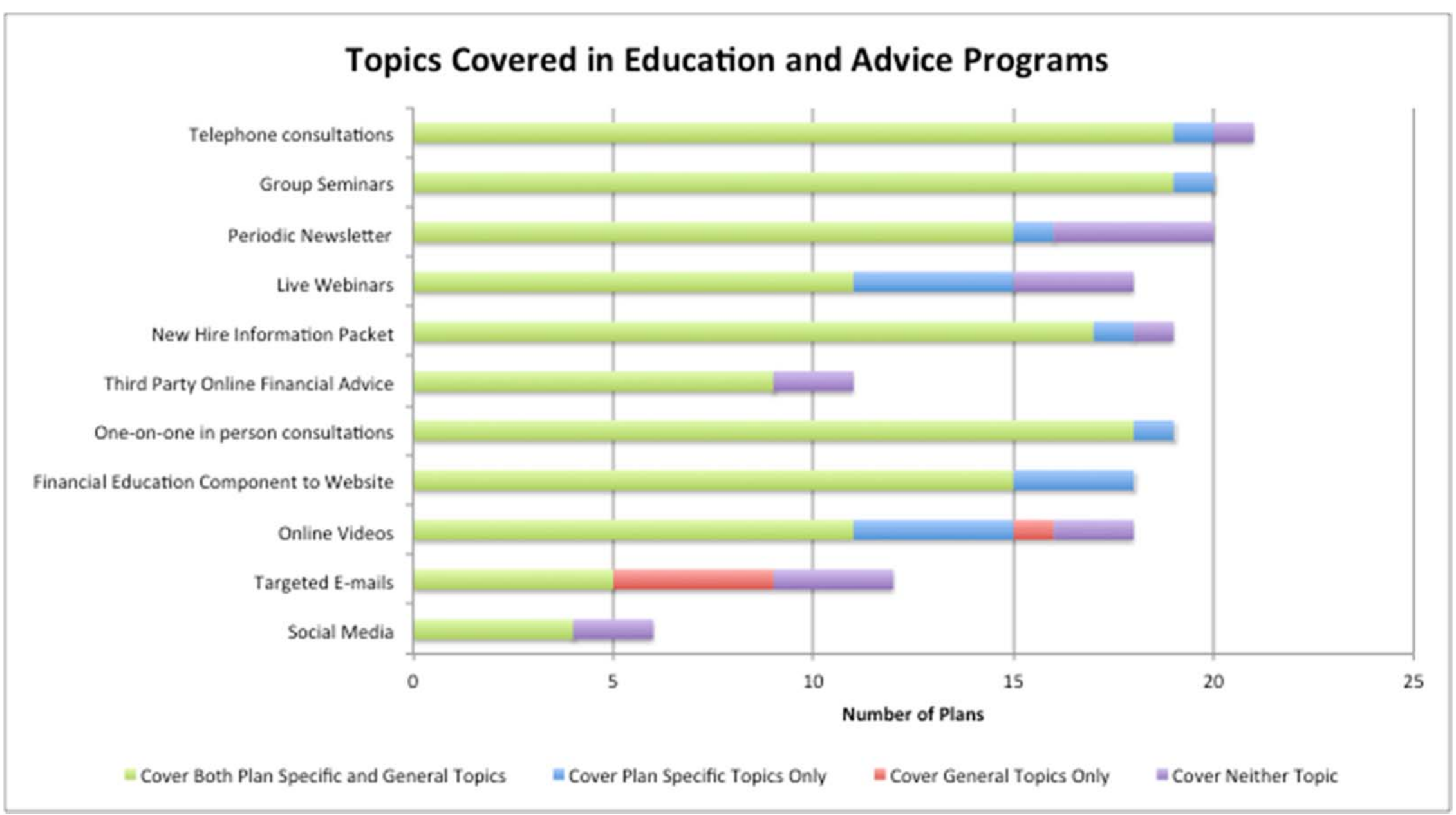


Figure 2: Florida Retirement System (FRS) Enrollments by Newly-Hired Employees

This table tracks the plan choice default rate from June 2003 to June 2012 for newly hired employees in the FRS.

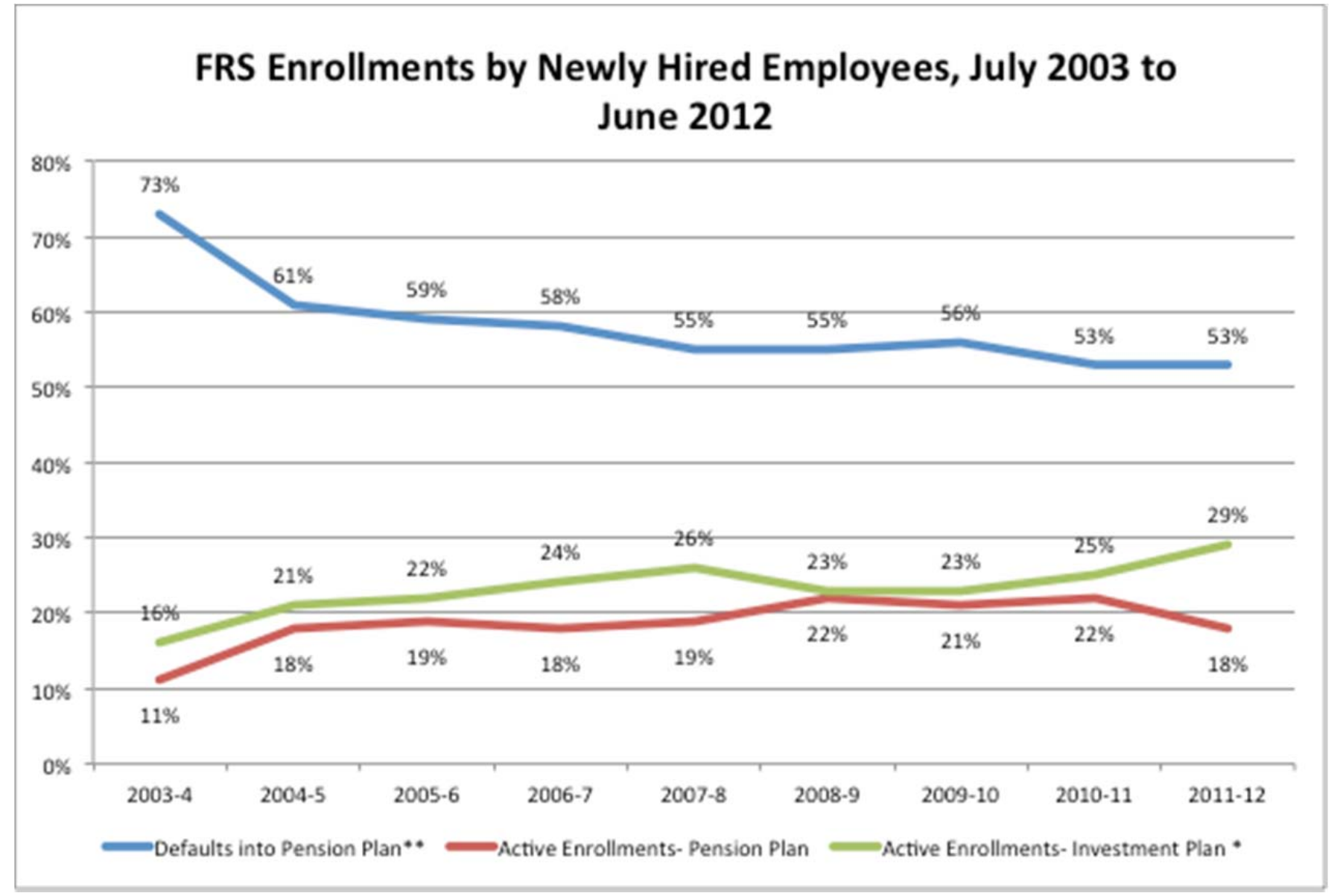

* Includes active enrollments into hybrid choice ** Up to 41 percent of defaulters may be using this option as their active election to the Pension Plan. Source: Fact Sheet: Update on Choice in the Florida Retirement System,” June 30, 2012 